\title{
Organocatalytic tandem Michael addition reactions: A powerful access to the enantioselective synthesis of functionalized chromenes, thiochromenes and 1,2-dihydroquinolines
}

\author{
Chittaranjan Bhanja ${ }^{1}$, Satyaban Jena ${ }^{1}$, Sabita Nayak ${ }^{2}$ \\ and Seetaram Mohapatra*2
}

\author{
Review \\ Address: \\ ${ }^{1}$ Department of Chemistry, Utkal University, Bhubaneswar-751 004, \\ Odisha, India and ${ }^{2}$ Department of Chemistry, Ravenshaw University, \\ Cuttack-753 003, Odisha, India, Fax: +91-671-2610304 \\ Email: \\ Seetaram Mohapatra* - seetaram.mohapatra@gmail.com \\ ${ }^{*}$ Corresponding author \\ Keywords: \\ chromenes; 1,2-dihydroquinolines; enantioselective; Michael addition; \\ organocatalytic; thiochromenes
}

Beilstein J. Org. Chem. 2012, 8, 1668-1694.

doi:10.3762/bjoc.8.191

Received: 02 April 2012

Accepted: 05 September 2012

Published: 04 October 2012

Associate Editor: D. Dixon

() 2012 Bhanja et al; licensee Beilstein-Institut.

License and terms: see end of document.

\begin{abstract}
Enantioselective organocatalysis has become a field of central importance within asymmetric chemical synthesis and appears to be efficient approach toward the construction of complex chiral molecules from simple achiral materials in one-pot transformations under mild conditions with high stereocontrol. This review addresses the most significant synthetic methods reported on chiralamine-catalyzed tandem Michael conjugate addition of heteroatom-centered nucleophiles to $\alpha, \beta$-unsaturated compounds followed by cyclization reactions for the enantioselective construction of functionalized chiral chromenes, thiochromenes and 1,2-dihydroquinolines in optically enriched forms found in a myriad of bioactive natural products and synthetic compounds.
\end{abstract}

\section{Introduction}

Chromenes or benzopyrans and their sulfur and nitrogen analogues are important classes of structural motifs found in numerous naturally occurring and synthetic compounds. Due to a rich array of functionalities and chiral centers these motifs are widely recognized as useful building blocks for the synthesis of a broad and interesting range of biologically active heterocyclic compounds having antiviral, antitumor, antimicrobial, antidia- betic, sex-pheromone, diuretic, anticoagulant, anti-anaphylatic and many more activities [1-9]. Some representative molecules of these structural motifs are shown in Figure 1 [9-21]. Therefore, synthetic methodologies allowing rapid access to these heterocycles in optically enriched form are highly desirable in organic synthesis and chemical biology/medicinal chemistry. In the past few years very promising progress has been made in 
<smiles>CC(C)=CCC/C(C)=C/CC[C@]1(C)C=Cc2c(cc(C)c(C(=O)O)c2O)O1</smiles>

Daurichromenic acid (anti-HIV)<smiles>CC1=CC2c3cc(O)ccc3OC(C)(C)[C@H]2CC1</smiles>

(+)-Conicol (antiproliferative antibacterial)<smiles>CCCCCCC(C)(C)c1cc(O)c2c(c1)OC(C)(C)[C@H]1CCC(=O)C[C@H]21</smiles>

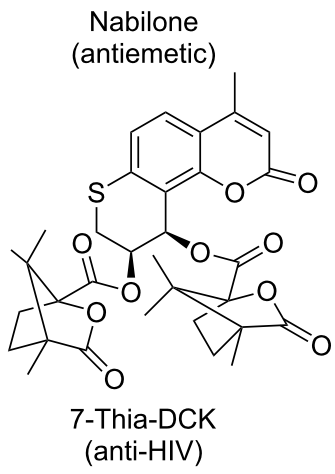<smiles>Cc1c(C)c2c(c(C)c1O)CC[C@@](C)(CCC[C@H](C)CCC[C@H](C)CCCC(C)C)O2</smiles>
$\alpha$-Tocopherol (anticancer)<smiles>CC1(C)Oc2ccc(C#N)cc2[C@H](N2CCCC2=O)C1O</smiles>

Levcromakalim (antihypertensive)<smiles>Oc1cc(O)c2c(c1)O[C@H](c1ccc(O)c(O)c1)[C@H](O)C2</smiles>

Catechin (anti-oxidant)<smiles>CC(C)(C)NC[C@H](O)CCc1cccc2c1SCCC2</smiles><smiles>CC1(C)C=Cc2c(ccc3c2OC(=O)CC3)O1</smiles>
Seselin (antitumor)<smiles>COc1ccc2c(c1)OC(C)(C)[C@H](c1ccccc1)[C@H]2c1ccc(OCCN2CCCC2)cc1</smiles>
(oral contraceptive)

Tetratolol (antidepressant)<smiles>CC(C)CC(=O)c1c(O)cc2c(c1O)[C@](C)(CC(C)C)C1=C(O2)C(C)(C)C(=O)C(C)(C)C1=O</smiles>

Rhodomyrtone (antibiotic)<smiles>NC(=O)c1ccc(F)c2c1CC(N(C1CCC1)C1CCC1)CO2</smiles>

Robalzotan (antidepressant, anxiolytic)<smiles>CN1c2ccccc2CCC1CCc1ccc2c(c1)OCO2</smiles>

(R)-(+)-Galipinine $\mathrm{X}$ (antimalarial, cytotoxic activity)<smiles>[R20]C(=O)c1ccc2c(c1)[C@@H]1[C@@H](CCN1C(=N)NCC=C(C)C)[C@@H](CCCNC(=N)NCC=C(C)C)N2</smiles>

Martinelline (1): $\mathrm{R}=\mathrm{H}_{2} \mathrm{~N}$ (antibiotic)

Figure 1: Some representative molecules having chromene, thiochromene or 1,2-dihydroquinolin structural motifs.

this intriguing area, and among the advances, organocatalytic enantioselective methodologies have gained much attention from many research groups worldwide [22-29]. In the meantime, organocatalytic tandem Michael conjugate additions of heteroatom-centered nucleophiles to $\alpha, \beta$-unsaturated compounds appear as one of the most reliable and powerful tools for the stereocontrolled access to a wide range of biologically active heterocycles in optically enriched form [29-32]. In this review we have summarized our efforts to cover various chiralamine-catalyzed synthetic protocols leading to one-pot enantioselective synthesis of six membered mono hetero-atom containing, biologically active heterocycles, such as functionalized chromenes (benzopyranes), thiochromenes (thiobenzopyranes) and 1,2-dihydroquinolines, by means of tandem/domino hetero Michael addition reactions, or modified versions [33-38], covering the literature up to 2011. Keeping an overview of organocatalytic modes of activation, and taking the less reactive Michael acceptor into account, we discuss here only the iminium/enamine activation or dual activation by iminium and hydrogen-bonding interaction strategies followed by cyclization, for these one-pot enantioselective syntheses. Wherever possible, working mechanistic models are presented. 


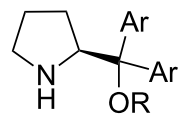

la: $\mathrm{Ar}=3,5-\left(\mathrm{CF}_{3}\right)_{2} \mathrm{C}_{6} \mathrm{H}_{3}, \mathrm{R}=\mathrm{TMS}$

lb: $\mathrm{Ar}=\mathrm{Ph}, \mathrm{R}=\mathrm{TMS}$

Ic: $\mathrm{Ar}=\mathrm{Ph}, \mathrm{R}=\mathrm{H}$

Id: Ar = 2-napthyl, $\mathrm{R}=\mathrm{TMS}$

le: $\mathrm{Ar}=\mathrm{Ph}, \mathrm{R}=\mathrm{TES}$

If: $\mathrm{Ar}=\mathrm{Ph}, \mathrm{R}=\mathrm{TBS}$<smiles>O=C(O)[C@H]1CCCN1</smiles>

IX<smiles>NC(=O)[C@@H]1CCCN1</smiles>

$\mathbf{X}$<smiles>COC(c1nccn1C)(c1nccn1C)[C@H]1CCCN1</smiles>

II<smiles>COC(c1ccc(CN(C)C)cc1)(c1ccc(CN(C)C)cc1)C1CCCN1</smiles>

III<smiles>COc1ccc(C(O[As])(c2ccc(OC)cc2)[C@@H]2CCCN2)cc1</smiles>

IV<smiles>C1CNC(c2nnn[nH]2)C1</smiles><smiles>C1CN[C@H](CN2CCCC2)C1</smiles>

XI<smiles>C1CNC(Cc2nnn[nH]2)C1</smiles>

VI<smiles>c1ccc(SCC2CCCN2)nc1</smiles>

VII<smiles>Cn1ccnc1SCC1CCCN1</smiles>

VIII<smiles>C1CNC(CN2CCOCC2)C1</smiles>

XV<smiles>[Al]NCC1CCCN1</smiles>

XVI<smiles>O=C(O)C1CCCN1</smiles>

XVII<smiles>Nc1ccccc1SCC1CCCN1</smiles>

XII<smiles>Cn1ccnc1SCC1CCCN1</smiles>

XIII<smiles>OC[C@H]1CCCN1</smiles>

XIV<smiles>[R]OC(=O)C1NCC[C@@H]1O</smiles>

XVIlla: $\mathrm{R}=\mathrm{H}$ XVIIIb: $R=R b$<smiles>O=C(O)N1CCCC1</smiles>

XIX<smiles>c1ccc([C@H](c2ccc[nH]2)C2CCCN2)cc1</smiles><smiles>C1CCNC1</smiles><smiles>[R4]Oc1ccc2nccc([C@@H](NC(=O)C3CCCN3)C3CC4(C=C)CCN3CC4)c2c1</smiles>

XXVI<smiles>CN1C(=O)[C@@H](Cc2ccccc2)N[C@@H]1C(C)(C)C</smiles><smiles>CN1C(=O)[C@@H](Cc2ccccc2)NC1(C)C</smiles><smiles>CN1C(=O)[C@@H](Cc2cnc[nH]2)NC1(C)C</smiles><smiles>CS(=O)(=O)C1CCCCC1NC(=O)C1CCCN1</smiles>

xxV

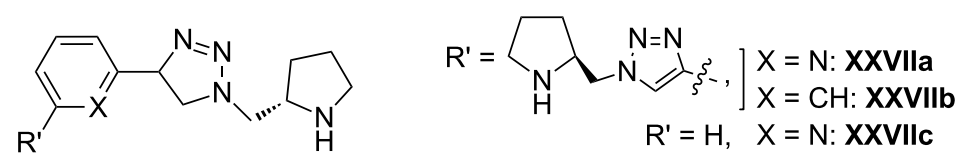

Figure 2: Screened chiral proline and its derivatives as organocatalysts. $\mathrm{Rb}=$ rubidium.

This review work is systematized under the headings (1) Organocatalytic oxa-Michael reactions to access functionalized chromenes; (2) Organocatalytic thio-Michael reactions to access functionalized thiochromenes; and (3) Organocatalytic azaMichael reactions to access functionalized 1,2-dihydroquinolines, using chiral proline and its derivatives (Figure 2), chiral bifunctional thioureas, cinchona alkaloids and other organocatalysts (Figure 3). For each reaction, the initial screening result of various organocatalysts with their percentage of conversion (\% yield) and enantiomeric excess (ee) is presented in tabular form, and the best catalyst is used for the given individual scheme.

\section{Review}

1 Organocatalytic oxa-Michael additions to access functionalized chromenes

\subsection{Reactions of 2-hydroxybenzaldehydes with} acyclic/cyclic $\alpha, \beta$-unsaturated compounds

The racemic synthesis of $2 \mathrm{H}$-chromene was reported by Bräse et al. in $2005[39,40]$. A strategy based on the organocatalytic enantioselective synthesis of chiral $2 \mathrm{H}$-chromenes through tandem-oxa-Michael-aldol sequence was first reported by Arvidsson et al. [41] in 2006, using diarylprolinolether as an effective organocatalyst. This method involved an oxa-Michael 


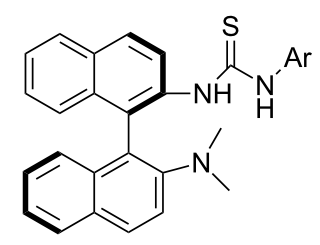

$\mathrm{Ar}=3,5-\left(\mathrm{CF}_{3}\right) \mathrm{C}_{6} \mathrm{H}_{3}$ XXVIII<smiles>C=CC1C2CCN1CC2C(O)c1ccnc2ccc(NC(=S)NC)cc12</smiles>

$\mathrm{Ar}=3,5-\left(\mathrm{CF}_{3}\right)_{2} \mathrm{C}_{6} \mathrm{H}_{3}$ $\mathrm{XXIX}$<smiles>N[C@@H](c1ccccc1)[C@H](NC(=S)NC1CCCCC1)c1ccccc1</smiles>

$\mathrm{Ar}=3,5-\left(\mathrm{CF}_{3}\right)_{2} \mathrm{C}_{6} \mathrm{H}_{3}$ $\mathrm{XXX}$<smiles>C=CC1CC2CCC1N2[C@H](NC(=S)NC(F)(F)F)c1ccnc2ccc(OC)cc12</smiles>

$\mathrm{Ar}=3,5-\left(\mathrm{CF}_{3}\right)_{2} \mathrm{C}_{6} \mathrm{H}_{3}$ XXXIa<smiles>C=CC1CC2CCC1N2[C@H](NC(=S)NC(C)Cl)c1ccnc2ccc(OC)cc12</smiles>

$\mathrm{Ar}=3,5-\left(\mathrm{CF}_{3}\right)_{2} \mathrm{C}_{6} \mathrm{H}_{3}$ XXXIb<smiles>C=CN1C2C=CC1C([C@H](NC(=S)N[C@@H](c1ccccc1)[C@H](O)c1ccccc1)c1ccnc3ccc(OC)cc13)C2</smiles><smiles>[R]Oc1ccc2nccc([C@@H]([R20])[C@H]3CC4C=CN3CC4)c2c1</smiles>

XXXIXa: $\mathrm{R}^{1}=\mathrm{H}, \mathrm{R}^{2}=\mathrm{H}$

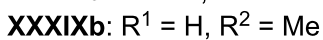
XXXIXc: $R^{1}=B n, R^{2}=H$<smiles>C=CC1CC2CCN1C2[C@H](N)c1ccnc2ccc(OC)cc12</smiles>

XLI<smiles>COc1ccc2nccc(C(NC(=S)NC3CCCCC3)C3CC4CCN3CC4)c2c1</smiles><smiles>CNC(=S)NC(c1ccnc2ccc(OC)cc12)C1CC2CCN1CC2</smiles>

$\mathrm{Ar}=3,5-\left(\mathrm{CF}_{3}\right)_{2} \mathrm{C}_{6} \mathrm{H}_{3}$ XXXIla<smiles>COc1ccc2nccc(C(NC(=S)Nc3ccccc3O)C3CC4CCN3CC4)c2c1</smiles>

XXXIII<smiles>COc1ccc2nccc(C(NC(=S)NC3c4ccccc4CC3O)C3CC4CCN3CC4)c2c1</smiles>

XXXIV

\section{XXXVla: $\operatorname{Ar}=(S)-1$-phenylethyl}

XXXVIb: $A r=(S)-1-($ naphthalene-1-yl)ethyl

XXXVIc: $\mathrm{Ar}=(S)$-1-(naphthalene-2-yl)ethyl XXXVId: $\mathrm{Ar}=3,5-\left(\mathrm{CF}_{3}\right)_{2} \mathrm{C}_{6} \mathrm{H}_{3}$<smiles>C=CN1C2CCC1C([C@H](O)c1ccnc3ccc(OC)cc13)C2</smiles><smiles>CNC(=S)NC1CCCCC1N(C)C</smiles>

$\mathrm{Ar}=3,5-\left(\mathrm{CF}_{3}\right)_{2} \mathrm{C}_{6} \mathrm{H}_{3}$ XXXVII<smiles>C=CC1CCC2(CCN2C(O)c2ccnc3ccc(OCC)cc23)C1</smiles><smiles>[R1]NC1CCCCC1NC(=S)N[Tl]</smiles>

$\mathrm{Ar}=3,5-\left(\mathrm{CF}_{3}\right)_{2} \mathrm{C}_{6} \mathrm{H}_{3}$

XXXVIIla: $\mathrm{R}^{1}=\mathrm{H}$

XXXVIIIb: $\mathrm{R}^{1}=\mathrm{Me}$<smiles>C=CC1CC2CCN1C2[C@H](O)c1ccnc2ccc(OC)cc12</smiles>

$\mathbf{X X X X}$<smiles>[C-]#[N+][C@H](c1ccnc2ccc(OC)cc12)C1CC2CCC1N2C=C</smiles>

XㄴII
XLa: $R^{1}=H, R^{2}=M e$

XLb: $R^{1}=$ phenanthryl, $R^{2}=H$<smiles>O=C(O)C1CCCCN1</smiles>

XLIII<smiles>N=C(N)N</smiles>

XLIV
$X L C$<smiles>CN(C)C(=N)N(C)C</smiles>

XLV

Figure 3: Screened chiral bifunctional thiourea, its derivatives, cinchona alkaloids and other organocatalysts.

attack of salicylaldehydes $\mathbf{1}$ on the $\alpha, \beta$-unsaturated aldehydes 2 activated through an iminium ion formation with the catalyst $\mathbf{I b}$, followed by an intramolecular aldol reaction and the subsequent water elimination to afford the chromene 3 (Scheme 1). The same reaction was also repeated with various catalysts, which are presented in Scheme 1. Several base and acid additives were found to affect both the enantioselectivities and the yields of the product. The overall reaction sequence provided chromenes with aromatic substituents at the $\mathrm{C}-2$ position in up to $70 \%$ yield and $60 \%$ enantioselectivity in dichloromethane at 
<smiles>[R]C=CC=O</smiles>

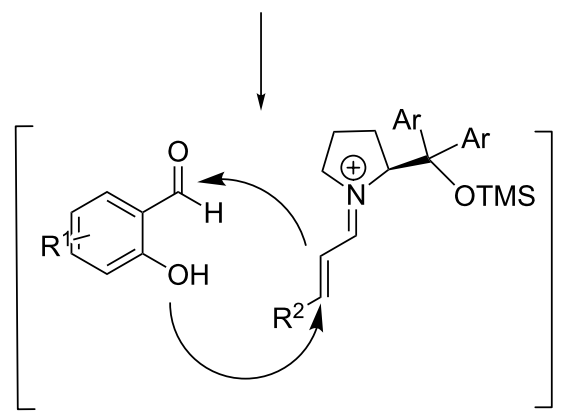

$\mathrm{R}^{1}=\mathrm{H}, 5-\mathrm{OMe}$

$\mathrm{R}^{2}=\mathrm{Ph}, 4-\mathrm{NO}_{2} \mathrm{C}_{6} \mathrm{H}_{4}, 2-\mathrm{NO}_{2} \mathrm{C}_{6} \mathrm{H}_{4}, n-\mathrm{Pr}$

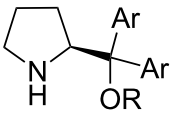

lb: $\mathrm{Ar}=\mathrm{Ph}, \mathrm{R}=\mathrm{TMS}$

Ic: $\mathrm{Ar}=\mathrm{Ph}, \mathrm{R}=\mathrm{H}$

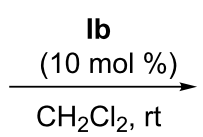<smiles>[R]C1Oc2cc[R17]cc2C=C1C=O</smiles>

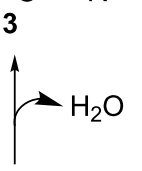<smiles>[R2]C1Oc2cc[R17](C)cc2C(O)C1C(=O)O</smiles>

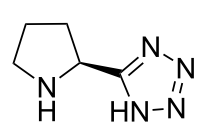

v

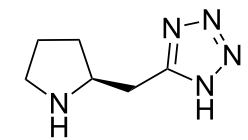

VI<smiles>CN1C(=O)C(Cc2ccccc2)NC1(C)C</smiles>

XXIII<smiles>CN1C(=O)[C@@H](Cc2cnc[nH]2)NC1(C)C</smiles>

XXIV

\begin{tabular}{llllccc} 
Catalyst & Ib & Ic & V & VI & XXIII & XXIV \\
\hline Yield (\%) & 70 & 20 & 0 & 5 & 0 & 0 \\
ee $(\%)$ & $90(R)$ & $22(R)$ & - & nd & - & -
\end{tabular}

$\mathrm{nd}=$ not determined

Scheme 1: Diarylprolinolether-catalyzed tandem oxa-Michael-aldol reaction reported by Arvidsson.

room temperature, while $\mathrm{C}-2$ aliphatic analogues were obtained in $90 \%$ enantiomeric excess, but with only $20 \%$ yield, under identical conditions.

Taking the advantages of the above methodology, Córdova et al. $[42,43]$ and subsequently Wang et al. [44] independently reported similar oxa-Michael/aldol reactions by means of the same iminium-ion activation strategies but with improved yields and enantioselectivities. Córdova et al. reported the tandem reaction of salicylaldehydes $\mathbf{1}$ and $\alpha, \beta$-unsaturated aldehydes $\mathbf{2}$ catalyzed by diphenylprolinol ether $\mathbf{I b}$ at a slightly higher catalyst loading $(20 \mathrm{~mol} \%)$ in toluene and with 2-nitrobenzoic acid as cocatalyst, which significantly increased the ee of the reaction from 9 to $88 \%$. Further enhancement of the yield was achieved by the use of molecular sieves $(4 \AA)$ in the reaction (Scheme 2).<smiles>[R]C=CC=O</smiles>

$\mathrm{R}^{1}=\mathrm{H}, 3-\mathrm{F}, 4-\mathrm{Me}$

$\mathrm{R}_{2}=\mathrm{Ph}, 4-\mathrm{ClC}_{6} \mathrm{H}_{4}, 4-\mathrm{CNC}_{6} \mathrm{H}_{4}, \mathrm{CO}_{2} \mathrm{Et}$

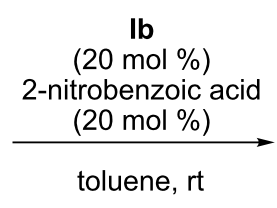

toluene, $r$

$\mathrm{R}^{1}$<smiles></smiles>

Yield: up to $95 \%$ ee: up to $88 \%$

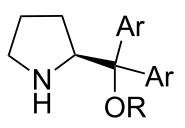

lb : $\mathrm{Ar}=\mathrm{Ph}, \mathrm{R}=\mathrm{TMS}$

Id: $\mathrm{Ar}=2$-naphthyl, $\mathrm{R}=\mathrm{TMS}$

\begin{tabular}{lll}
\hline Catalyst & Ib & Id \\
Conversion (\%) & 18 & 4 \\
ee $(\%)$ & $21(R)$ & $44(R)$
\end{tabular}




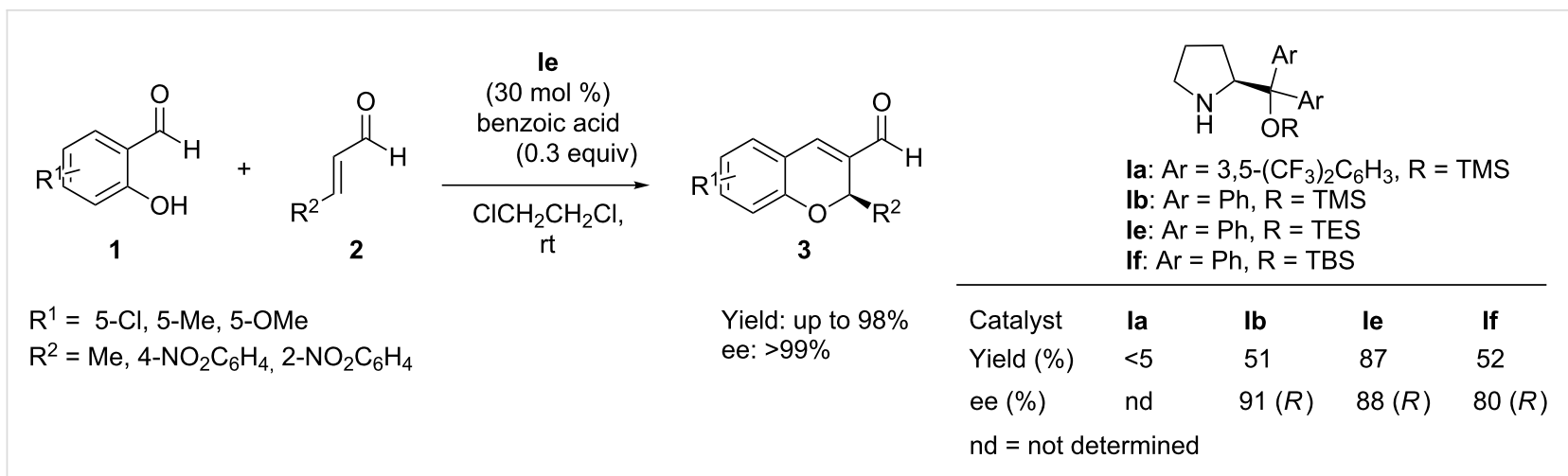

Scheme 3: Domino oxa-Michael-aldol reaction developed by Wei and Wang.

Wang et al. [44] investigated the same tandem reaction of salicylaldehydes 1 and $\alpha, \beta$-unsaturated aldehydes 2 employing TES-protected diphenylprolinol Ie as organocatalyst with high catalyst loading ( $30 \mathrm{~mol} \%$ ). With benzoic acid as cocatalyst and dichloroethane as solvent, the test reaction provided the chiral chromenes 3 in good yields (up to 98\%) and enantioselectivities $(99 \%)$ at room temperature (Scheme 3 ).

In 2009, Xu et al. [45] developed an efficient protocol for the asymmetric tandem oxa-Michael-aldol reaction using chiral amine/chiral acid organocatalyst, instead of only organocatalyst, for the enantioselective synthesis of $2 \mathrm{H}$-chromenes. In the reported protocol, the reaction of salicylaldehydes 1 with $\alpha, \beta-$ unsaturated aldehydes 2 catalyzed by $(S)$-diphenylprolinol trimethylsilyl ether Ib with $(S)$-Mosher acid Ib' afforded the desired products 3 with high yield (45-90\%) and with high enantioselectivity (77-99\%) (Scheme 4). The reaction proceeded through the iminium intermediate, and the synergistic ionic interaction of chiral amine with chiral acid formed in situ in the catalytic system effected an improvement of the reaction performance and offered an efficient steric effect in the transformation. Although the reaction tolerated a broad scope of substrates, the yields as well as enantioselectivities were greatly affected by the electronic and steric effect of the substrates. Compound 1 bearing electron-donating groups afforded the desired product with high yield (up to 90\%) and enantioselectivity (up to $99 \%$ ), whereas compound 2 having electronwithdrawing groups provided poor results.

Very recently, Xu et al. [46] reported an improved protocol for the domino-oxa-Michael reaction of salicylaldehydes $\mathbf{1}$ with $\alpha, \beta$-unsaturated aldehydes $\mathbf{2}$ employing tertiary amine-modified diarylpyrrolinol-TMS ether III as a water-soluble and recyclable organocatalyst with 4-chlorobenzoic acid as cocatalyst (Scheme 5) for the synthesis of $2 \mathrm{H}$-chromene derivatives 3 . The electronic effect of the tertiary amine group in the modified catalyst was believed to enhance the enantioselectivity of the chiral secondary amine. Since the catalyst is soluble in water, the method provides the pure product with excellent enantioselectivity. The reaction appears to have a broad scope,<smiles>[R]C=CC=O</smiles>

$\mathrm{R}^{1}=\mathrm{H}, 5-\mathrm{OMe}$, 3-OMe, 5- $\mathrm{Cl}, 5-\mathrm{NO}_{2}$

$\mathrm{R}^{2}=4-\mathrm{MeC}_{6} \mathrm{H}_{4}, 4-\mathrm{ClC}_{6} \mathrm{H}_{4}, \mathrm{Ph}, 4-\mathrm{CF}_{3} \mathrm{C}_{6} \mathrm{H}_{4}$, 4-OMe, thiophen-2-yl

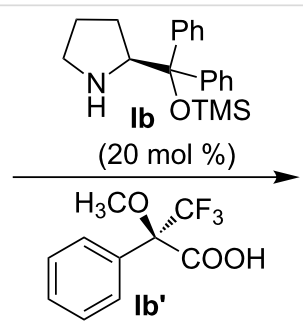

ether, rt, $0.5 \mathrm{~h}, \mathrm{MS} 4 \AA$

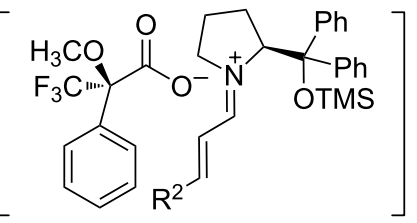

proposed transition-state model<smiles>[R]C1OC2=C(C=C[R17]C=C2)C=C1C=O</smiles>

Yield: $45-90 \%$ ee: $77-99 \%$ 


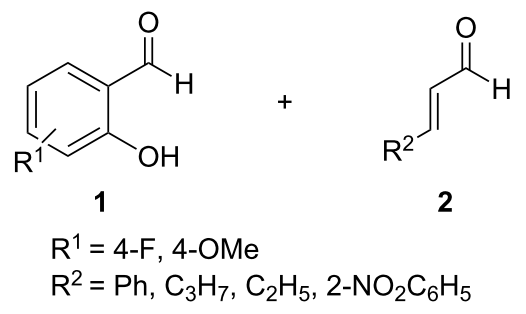<smiles>[R1]c1ccc2c(c1)OC([R])C(C=O)=C2</smiles>

Yield: $22-93 \%$ ee: $53-93 \%$

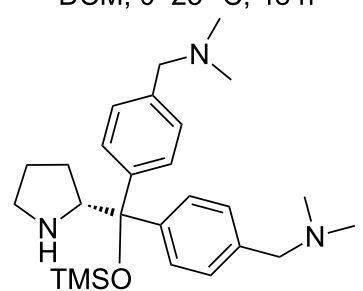

III

Scheme 5: Modified diarylproline ether as amino catalyst in oxa-Michael-aldol reaction as reported by Xu and co-workers.

but efficiencies (22-93\% yield) and enantioselectivities (53-93\% ee) vary with the electronic and steric nature of 1 and 2 .

A potential "one-pot" approach to the organocatalytic synthesis of chiral $4 \mathrm{H}$-chromenes was first reported by Wang and co-workers [47]. In an unprecedented oxa-Michael-aldol cascade sequence, reactions of (2-hydroxyphenyl)-2-oxoac- etates 4 (Michael donor) and alkynals 5 (Michael acceptor) afforded highly functionalized chiral $4 H$-chromenes $\mathbf{6}$ with a quaternary stereogenic center, by means of the less explored iminium-allenamine activation strategy. Among the screened chiral secondary amine catalysts, $(S)$-diphenylpyrrolinol tertiary butyldimethylsilylether If in toluene provides good yields and high enantiomeric excess of $4 H$-chromenes 6 with a wide range of substrates (Scheme 6).<smiles>CCOC(=O)c1cc[R1]cc1O</smiles>

4<smiles>C1CCCCC1</smiles>

$\mathrm{R}^{1}=5-\mathrm{OMe}, 4-\mathrm{OMe}$ 4-Me, 4-Cl, $\mathrm{H}$<smiles>[R]C#CC=O</smiles>

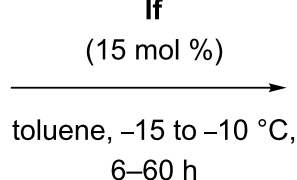
6-60 h<smiles>C=C</smiles>
5<smiles>CS(=O)(=O)c1ccccc1</smiles><smiles>CI</smiles>

$\mathrm{R}^{2}=\mathrm{Ph}, 4-\mathrm{OMeC}_{6} \mathrm{H}_{4}, 4-\mathrm{ClC}_{6} \mathrm{H}_{4}, 4-\mathrm{BrC}_{6} \mathrm{H}_{4}, 4-\mathrm{FC}_{6} \mathrm{H}_{4}$, 4- $\mathrm{NO}_{2} \mathrm{C}_{6} \mathrm{H}_{4}$, 2-thienyl, 2-furanyl, $t$-Bu<smiles>[R]C1=C(C=O)C(O)(C(=O)OCC)c2cc[R17]cc2O1</smiles>

ee: 93 to $>99 \%$
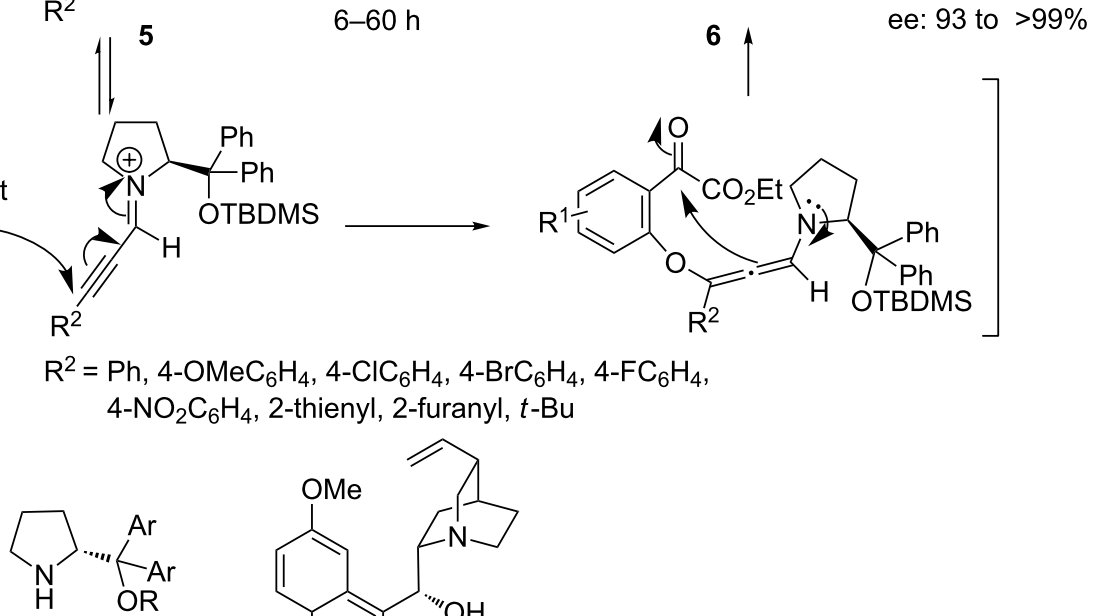

lb: $A r=P h, R=T M S$

le: $A r=P h, R=T E S$<smiles>C=CC1CC2CCN1CC2[C@H](O)c1ccnc2ccc(OC)cc12</smiles>

If: $\mathrm{Ar}=\mathrm{Ph}, \mathrm{R}=\mathrm{TBDMS}$

XLC

\begin{tabular}{llllr}
\hline Catalyst & lb & le & If & XLc \\
Yield (\%) & 97 & 98 & 98 & $<5$ \\
ee $(\%)$ & $97(R)$ & $98(R)$ & $98(R)$ & nd \\
nd = not determined & & &
\end{tabular}

Scheme 6: Chiral secondary amine promoted oxa-Michael-aldol cascade reactions as reported by Wang and co-workers. 
The potential of less well-explored alkynals as Michael acceptors was further explored, when Alemán et al. [48] in 2010 reported the synthesis of chiral 4-amino- $4 H$-chromene 8 by reaction of salicyl- $N$-tosylimine 7 (Michael donor) with 2-alkynals 5 using diarylprolinolether Ia as organocatalyst (Scheme 7). The reactions were carried out in toluene at room temperature and completed within $2 \mathrm{~h}$, giving high yield $(>97 \%)$ and excellent enantioselectivity (99\%). Mechanistically the reaction proceeded through oxa-Michael addition followed by aza-Baylis-Hillman reaction by means of an iminiumallenamine activation strategy.

Later on, the same authors [49] in 2011 reported a similar tandem reaction (abnormal Baylis-Hillman) between 2-alkynals $\mathbf{5}$ and salicylaldehyde derivatives $\mathbf{1}$ catalyzed by proline derivatives (prolinamide or prolinol) leading to optically active 4-hydroxy-4 $H$ chromene-3-carbaldehydes 9 (Scheme 8). The reactions proceeded with good yields and enantiomeric ratio up to $98: 2$ by using the bulky catalyst prolinol diphenyl silylether Ia in dichloromethane/ethanol (1:1) at room temperature.

Cyclic $\alpha, \beta$-unsaturated ketones have also responded as Michael acceptors in the organocatalytic tandem Michael addition reaction towards the synthesis of tetrahydroxanthones. Córdova et al. [50], in 2007, reported the first organocatalytic asymmetric synthesis of tetrahydroxanthenones through the domino Michael-aldol reaction of salicylaldehyde derivatives $\mathbf{1 0}$ and $\alpha, \beta$-unsaturated cyclic ketones 11. Using chiral pyrrolidine XI as organocatalyst and 2-nitrobenzoic acid as additive, the reaction of salicylaldehydes and $\alpha, \beta$-unsaturated cyclic ketones afforded the corresponding tetrahydroxanthones $\mathbf{1 2}$ with moderate yields (up to 56\%) and enantioselectivities in the<smiles>Oc1ccccc1/C=N/[As]</smiles><smiles></smiles>

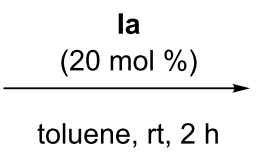

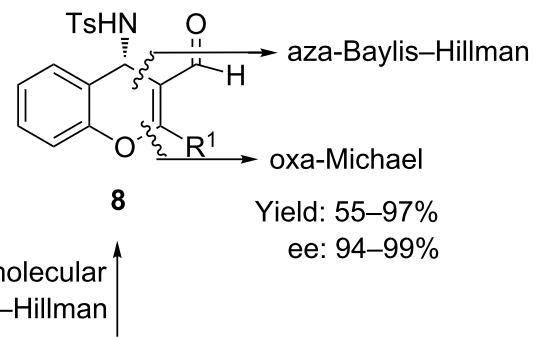

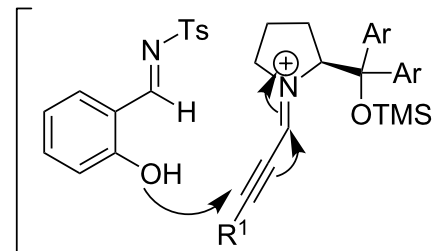

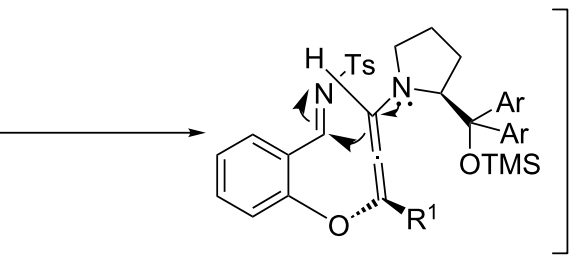

$\mathrm{R}^{1}=\mathrm{Ph}, 4-\mathrm{MeC}_{6} \mathrm{H}_{4}, 4-\mathrm{OMeC}_{6} \mathrm{H}_{4}, 2-\mathrm{MeC}_{6} \mathrm{H}_{4}, 3,5-\left(\mathrm{CF}_{3}\right)_{2} \mathrm{C}_{6} \mathrm{H}_{4}$, 4-t- $\mathrm{BuC}_{6} \mathrm{H}_{4}, 4-\left(\mathrm{C}_{5} \mathrm{H}_{11}\right) \mathrm{C}_{6} \mathrm{H}_{4}, n$-pentyl, TMS, 1-cyclohexenyl<smiles>[R]C([123I])([131I])C1CCCN1</smiles><smiles>O=C(O)C1CCCN1</smiles>

IX<smiles>NC(=O)C1CCCN1</smiles>

$\mathbf{x}$

la: $\mathrm{Ar}=3,5-\left(\mathrm{CF}_{3}\right)_{2} \mathrm{C}_{6} \mathrm{H}_{3}, \mathrm{R}=\mathrm{TMS}$

lb: $\mathrm{Ar}=\mathrm{Ph}, \mathrm{R}=\mathrm{TMS}$

lc: $A r=P h, R=H$

\begin{tabular}{lllllc}
\hline Catalyst & la & lb & lc & IX & $\mathbf{X}$ \\
Yield (\%) & 95 & 77 & $\mathrm{nr}$ & $\mathrm{nr}$ & $>98$ \\
ee $(\%)$ & $96(S)$ & $98(S)$ & - & - & $33(S)$
\end{tabular}

Scheme 7: Reaction of salicyl- $N$-tosylimine with aldehydes by domino oxa-Michael/aza-Baylis-Hillman reaction, as reported by Alemán and co-workers. 
<smiles>[R]C#CC=O</smiles>

$\mathrm{R}^{1}=\mathrm{H}, 3-\mathrm{OMe}, 4-\mathrm{OMe}, 5-\mathrm{OMe}, 5-\mathrm{Me}, 5-\mathrm{Cl}, 5-\mathrm{NO}_{2}$ $\mathrm{R}^{2}=\mathrm{Ph}, 4-\mathrm{OMeC}_{6} \mathrm{H}_{4}, 4-t-\mathrm{BuC}_{6} \mathrm{H}_{4}, 3,5-\left(\mathrm{F}_{3} \mathrm{C}\right)_{2} \mathrm{C}_{6} \mathrm{H}_{3}$, TMS

$\mathrm{rt}, \mathrm{DCM} / \mathrm{EtOH}$ la

$(20 \mathrm{~mol} \%)$

$\mathrm{R}^{1 \frac{\sqrt{1}}{\mathrm{i}}}$<smiles>[R]C1=C(C=O)C(O)c2ccccc2O1</smiles>

Yield: $62-92 \%$

ee: up to $98 \%$<smiles>[R]C([17N])([18F])C1CCCN1</smiles>

la: $\mathrm{Ar}=3,5-\left(\mathrm{CF}_{3}\right)_{2} \mathrm{C}_{6} \mathrm{H}_{3}, \mathrm{R}=\mathrm{TMS}$

lb: $\mathrm{Ar}=\mathrm{Ph}, \mathrm{R}=\mathrm{TMS}$

lc: $\mathrm{Ar}=\mathrm{Ph}, \mathrm{R}=\mathrm{H}$

\begin{tabular}{lllllc}
\hline Catalyst & la & lb & Ic & IX & $\mathbf{X}$ \\
Yield $(\%)$ & $>98$ & $>98$ & $\mathrm{nr}$ & $\mathrm{nr}$ & $>5$ \\
ee $(\%)$ & $70(R)$ & $64(R)$ & - & - & -
\end{tabular}

Scheme 8: Silyl prolinol ether-catalyzed oxa-Michael-aldol tandem reaction of alkynals with salicylaldehydes reported by Alemán group.

range of $85-91 \%$ ee (Scheme 9). Mechanistically the reaction involves the iminium activation of the $\alpha, \beta$-unsaturated cyclic enones by the chiral pyrrolidine catalyst.
Very recently, $\mathrm{Xu}$ and co-workers [51] reported an improved protocol for the same reaction employing a chiral pyrrolidine bearing a 2-mercaptopyridine moiety as organocatalyst (VII)<smiles>[R]c1cc([R2])c(O)c(C=O)c1</smiles>

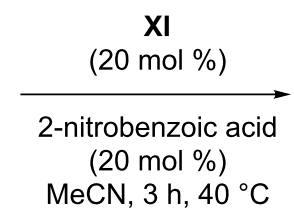

$\mathrm{MeCN}, 3 \mathrm{~h}, 40^{\circ} \mathrm{C}$<smiles>O=C(O)[C]1CCCN1</smiles>

IX

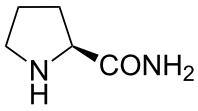

$\mathbf{X}$

10 11<smiles>[R]c1cc([R2])c2c(c1)C=C1C(=O)CCC([R])([R])C1O2</smiles>

12
Yield: $51-56 \%$ ee: $85-91 \%$<smiles>[R]CCCCO</smiles>
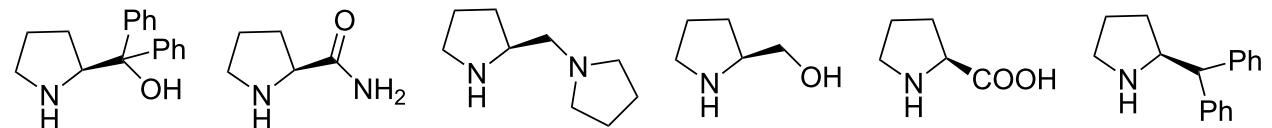

\begin{tabular}{ll} 
& Ic \\
\hline Catalyst & Ic \\
Yield (\%) & $\mathrm{nr}$ \\
ee (\%) & -
\end{tabular}

$\mathbf{X I}$

$\mathbf{X I}$

58

$77(R)$
XIV

XIV

22

$54(R)$ 
and simple $\alpha$-amino acids, such as tert-leucine, as co-catalyst. The asymmetric transformation proceeds by simultaneous activation of cyclic enones $\mathbf{1 3}$ and aldehyde $\mathbf{1}$ by the bifunctional catalyst VII and the amino acid, respectively, via the generation of a transient ion pair through iminium and imine intermediates. The reaction afforded the corresponding tetrahydroxanthenones 14 in excellent yields (95\%) and enantioselectivities (95\%) (Scheme 10).

\subsection{Reaction of 2-hydroxycinnamaldehydes/2- hydroxy- $\beta$-nitrostyrene with acyclic $\alpha, \beta$-unsaturated compounds}

In the previously reported organocatalytic tandem oxaMichael-aldol reactions, the instantaneous dehydration of the $\beta$-hydroxyaldimine intermediates generates products with only one stereogenic center. Hong et al. [52] in 2009 reported a novel quadruple-cascade reaction for constructing highly functionalized and enantiomerically enriched tetrahydro- $6 \mathrm{H}$ benzo $[c]$ chromenes with five stereogenic centers. The reaction involved a domino oxa-Michael-Michael-Michael-aldol condensation of $o$-hydroxy- $\beta$-nitrostyrene $\mathbf{1 5}$ and two equivalents of $\alpha, \beta$-unsaturated aldehydes in the presence of diphenylpyrrolinol trimethylsilyl ether Ib with an acid additive (HOAc/4-nitrobenzoic acid) in toluene at ambient temperature, which afforded tetrahydro- $6 H$-benzo[c]chromenes $\mathbf{1 8}$ in high diastereoselectivity and excellent enantioselectivity ( $>99 \%$ ee) (Scheme 11). The proposed mechanism of the cascade reaction starts in an analogous manner to that previously mentioned,<smiles>O=C(P)c1cc[R17]cc1O</smiles><smiles>O=C1C=CCCC1</smiles>

13

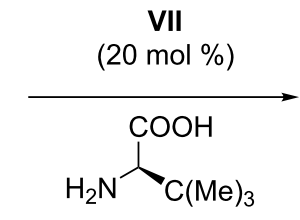

(20 $\mathrm{mol} \%)$

1,4-dioxane

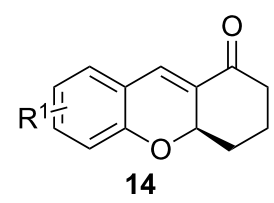

Yield: $95 \%$

ee: $95 \%$ 


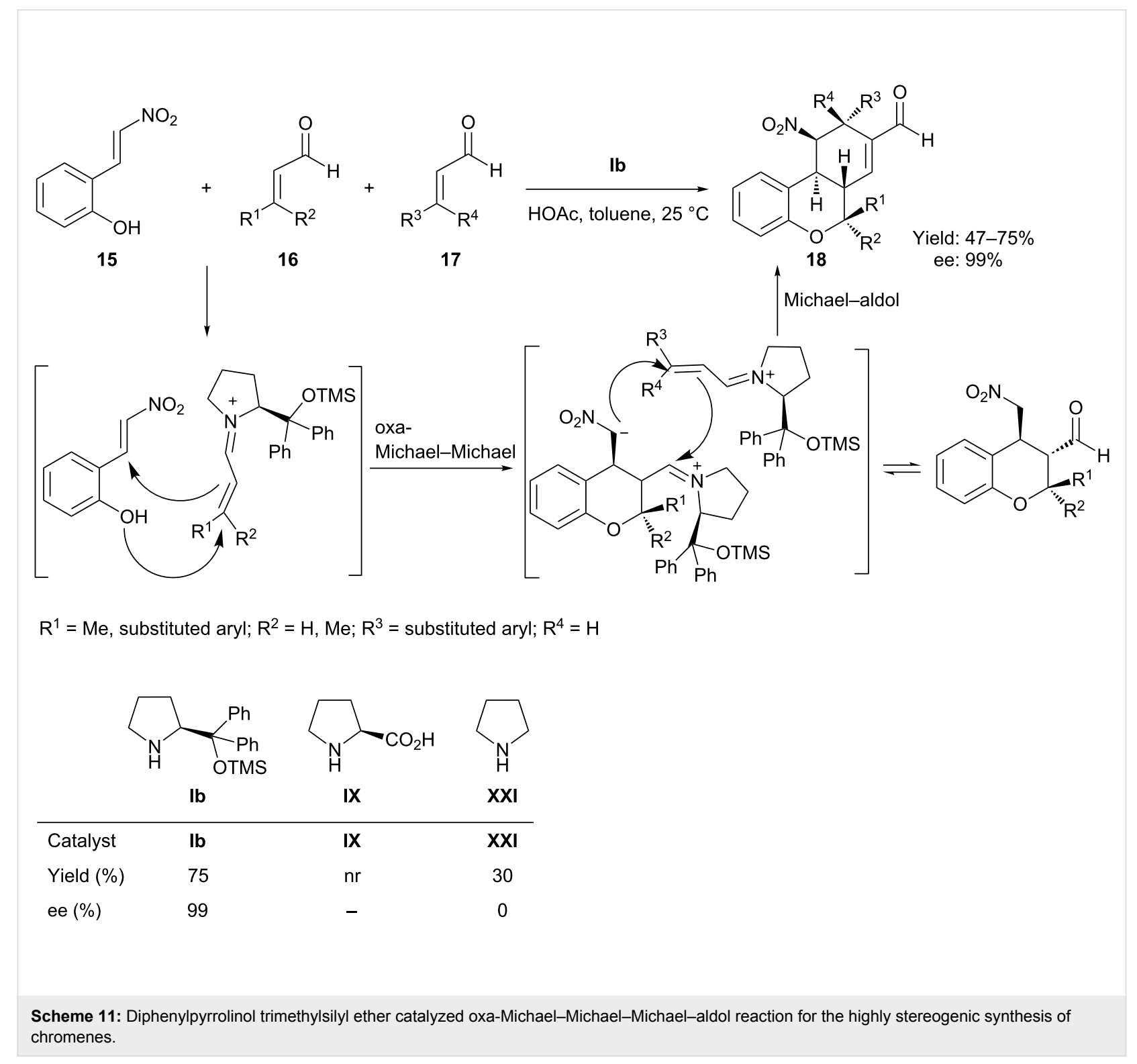

although the first oxa-Michael step is followed by a second Michael addition to form the chroman unit. A series of $\alpha, \beta$ unsaturated aldehydes were reacted with the $o$-hydroxy- $\beta$ nitrostyrene as shown in Scheme 11. Except for the observation of a trace of intermediate, only one enantiomer was observed in this reaction, probably due to the first oxa-Michael addition, which is known to proceed with high diastereo- and enantioselectivity, and the resulting product presumably directs the stereochemistry of the subsequent reactions. This quadruplecascade reaction exemplifies an efficient three-component reaction.

In 2010 Wang et al. [11] reported the highly enantioselective synthesis of trisubstituted chiral $4 H$-chromenes 20 through iminium-allenamide catalysis. The reaction consists of a
Michael-Michael-cascade sequence between alkynals 5 and $o$-hydroxy- $\beta$-nitrostyrenes $\mathbf{1 9}$, catalyzed by diphenylprolinol TBDMS ether If as catalyst in toluene at $0{ }^{\circ} \mathrm{C}$ (Scheme 12). Mechanistically, alkynals were involved in an unprecedented iminium-allenamine sequence and afforded highly functionalized $4 H$-chromenes in high yields (92-98\%) and with high ee $(>99 \%)$.

Extending the methodology adopted by Hong et al., the same group [53] reported a diastereoselective domino oxaMichael-Michael-Michael-aldol reaction as the key step for the construction of the hexahydro- $6 H$-benzo $[c]$ chromene skeleton of the biologically active natural product $(+)$-conicol (26). The protocol involved a tandem oxa-Michael-Michael reaction of 3-methyl-but-2-enal (22) and (E)-2-(2-nitrovinyl)- 
<smiles>O=[N+]([O-])C=Cc1cc[R1]cc1O</smiles>

19

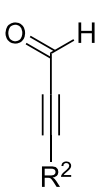

5

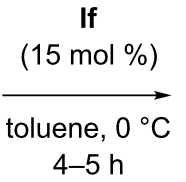

$\mathrm{R}^{1}=\mathrm{H}, 4-\mathrm{Cl}, 6-\mathrm{OMe}, 4-\mathrm{OMe}$

$\mathrm{R}^{2}=\mathrm{Ph}, 4-\mathrm{BrC}_{6} \mathrm{H}_{4}, 3-\mathrm{NO}_{2} \mathrm{C}_{6} \mathrm{H}_{4}, 4-\mathrm{OMeC}_{6} \mathrm{H}_{4}, t-\mathrm{Bu}, 4-\mathrm{MeC}_{6} \mathrm{H}_{4}$<smiles>[R]C1=C(C=O)C(C[N+](=O)[O-])c2cc[R1]cc2O1</smiles>

20

Yield: $92-98 \%$

ee: 98 to $>99 \%$

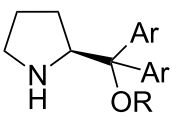

la: $\mathrm{Ar}=3,5-\left(\mathrm{CF}_{3}\right)_{2} \mathrm{C}_{6} \mathrm{H}_{3}, \mathrm{R}=\mathrm{TMS}$

lb: $\mathrm{Ar}=\mathrm{Ph}, \mathrm{R}=\mathrm{TMS}$

le: $\mathrm{Ar}=\mathrm{Ph}, \mathrm{R}=\mathrm{TES}$

If: $\mathrm{Ar}=\mathrm{Ph}, \mathrm{R}=\mathrm{TBDMS}$

\begin{tabular}{llllll}
\hline Catalyst & la & lb & le & If & XI \\
Yield (\%) & 90 & 95 & 93 & 97 & 91 \\
ee (\%) & $96(R)$ & $97(R)$ & $98(R)$ & $99(R)$ & $66(R)$
\end{tabular}

Scheme 12: Enantioselective cascade oxa-Michael-Michael reaction of alkynals with 2-(E)-(2-nitrovinyl)-phenols reported by Wang.

benzene-1,4-diol (21) followed by a domino Michael-aldol condensation with aldehyde $\mathbf{2 4}$ in the presence of TMS-protected diphenylprolinol $\mathbf{I b} / \mathrm{AcOH}$ as catalyst, affording the hexahydro$6 H$-benzo $[c]$ chromene skeleton 25 (Scheme 13). The two reactions could be achieved in one pot, without the isolation of intermediate, in $55 \%$ overall yields.
1.3. Reaction of 2-hydroxycinnamaldehydes/2hydroxy- $\beta$-nitrostyrenes with $\alpha, \beta$-unsaturated nitro compounds

Catalytic synthesis of nitrochromenes from salicylaldehydes and $\alpha, \beta$-unsaturated nitro compounds are well documented in literature [54-59], but there are very few reports on the

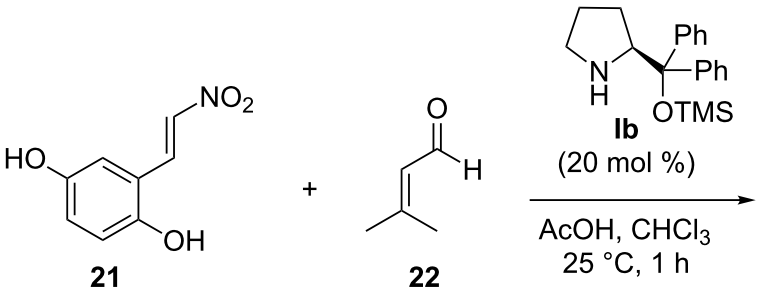

22<smiles>CC1(C)Oc2ccc(O)cc2[C@@H](C[N+](=O)[O-])[C@@H]1C=O</smiles>

23

Ib

(20 mol \%)

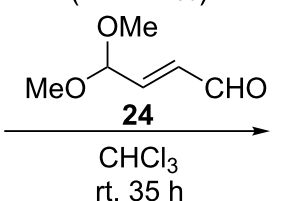

rt, $35 \mathrm{~h}$

Yield: $76 \%$ ee: $99 \%$<smiles>COC(OC)[C@H]1C(C=O)=C[C@H]2[C@H](c3cc(O)ccc3OC2(C)C)[C@H]1[N+](=O)[O-]</smiles>

25

Yield: $69 \%$ ee: $99 \%$

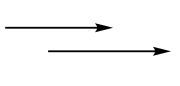

$\mathrm{HO}$<smiles>CC1=CC2CCCCC2(C)Oc2ccc(O)cc21</smiles>

26

(+)-Conicol

Scheme 13: Domino oxa-Michael-Michael-Michael-aldol reaction of 2-(2-nitrovinyl)-benzene-1,4-diol with $\alpha, \beta$-unsaturated aldehydes presented by Hong group. 
organocatalyzed synthesis of chiral nitrochromenes. Xu et al. [60] in 2008 first reported a novel organocatalytic tandem oxaMichael-Henry reaction between salicylaldehydes $\mathbf{1}$ and nitroalkenes 27 employing (S)-1-methyl-2-(pyrrolidin-2ylmethylthio)-1 $H$-imidazole (VIII) as organocatalyst in the presence of salicylic acid as cocatalyst and in DMSO as solvent (Scheme 14). The reaction was interpreted as following an aromatic iminium activation strategy and provided $2 H$-nitrochromene derivatives $\mathbf{2 8}$ with moderate yields and moderate to good enantioselectivities. One of the limitations of this methodology is that only aromatic nitroalkenes tolerate the reaction conditions.
Subsequently a closely related reaction of salicylaldehydes 29 with $\beta$-nitrostyrene (27) employing pyrrolidine-triazole-based C2 symmetric organocatalysts XXVIIa was reported by Sankararaman et al. [61] for the asymmetric synthesis of nitrochromenes 30 (Scheme 15). The reaction gave poor enantioselectivities both in toluene $(15 \%$ ee) and in DMF (24\% ee).

In 2010, Das et al. [62] reported an organocatalytic synthesis of 3-nitro-2-phenyl-2H-chromenes $\mathbf{3 2}$ without using any cocatalyst. The synthetic protocol involved an oxa-Michael-aldol reaction between salicylaldehydes $\mathbf{3 1}$ and $\beta$-nitrostyrene 27 in<smiles>[R]C=C[N+](=O)[O-]</smiles>

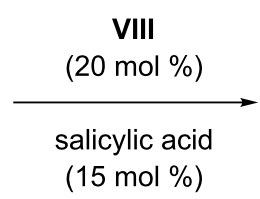

DMSO, rt<smiles>[R]C1Oc2cc[nH+]cc2C=C1[N+](=O)[O-]</smiles>

28 Yield: $10-67 \%$ ee: $70-85 \%$

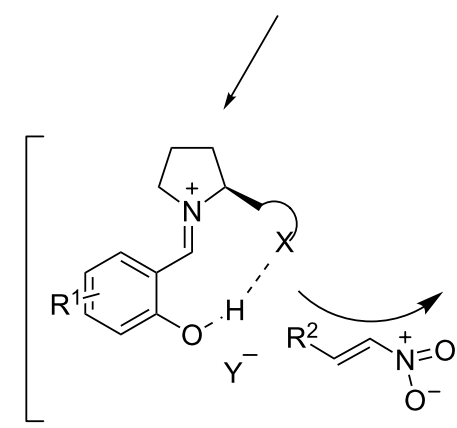

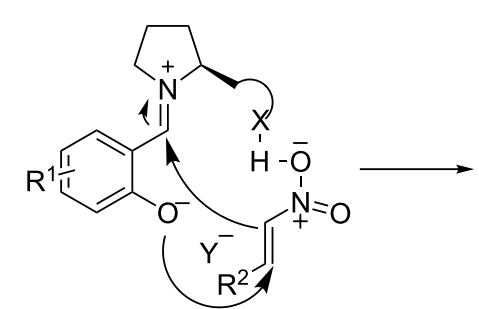

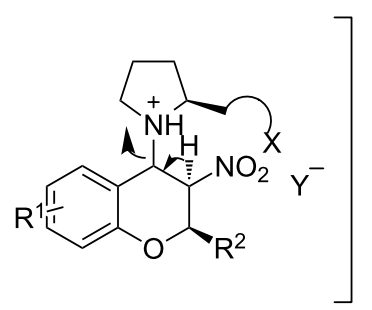

$\mathrm{R}^{1}=\mathrm{H}, 5-\mathrm{Cl}, 4-\mathrm{OMe}, 3-\mathrm{OMe}$

$\mathrm{R}^{2}=\mathrm{Ph}, 4-\mathrm{ClC}_{6} \mathrm{H}_{4}, 4-\mathrm{BrC}_{6} \mathrm{H}_{4}, 2-\mathrm{OMeC}_{6} \mathrm{H}_{4}, 4-\mathrm{MeC}_{6} \mathrm{H}_{4}$

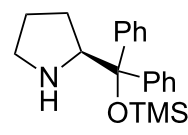

Ib<smiles>OC(c1ccccc1)(c1ccccc1)C1CCCN1</smiles>

Ic<smiles>c1ccc(SCC2CCCN2)nc1</smiles>

VII<smiles>Cn1ccnc1SCC1CCCN1</smiles>

VIII<smiles>O=C(O)C1CCCN1</smiles>

IX<smiles>C1CN[C@H](CN2CCCC2)C1</smiles><smiles>Nc1ccccc1SCC1CCCN1</smiles>

XII<smiles>OCC1CCCN1</smiles><smiles>C1CN[C@H](CN2CCOCC2)C1</smiles>

XIV

\begin{tabular}{llllllllll}
\hline Catalyst & Ib & Ic & VII & VIII & IX & XI & XII & XIV & XV \\
Yield (\%) & 14 & 17 & 36 & 67 & 13 & $<5$ & 47 & 21 & 30 \\
ee $(\%)$ & 0 & 0 & $72(R)$ & $85(R)$ & 0 & nd & $76(R)$ & 0 & $70(R)$
\end{tabular}




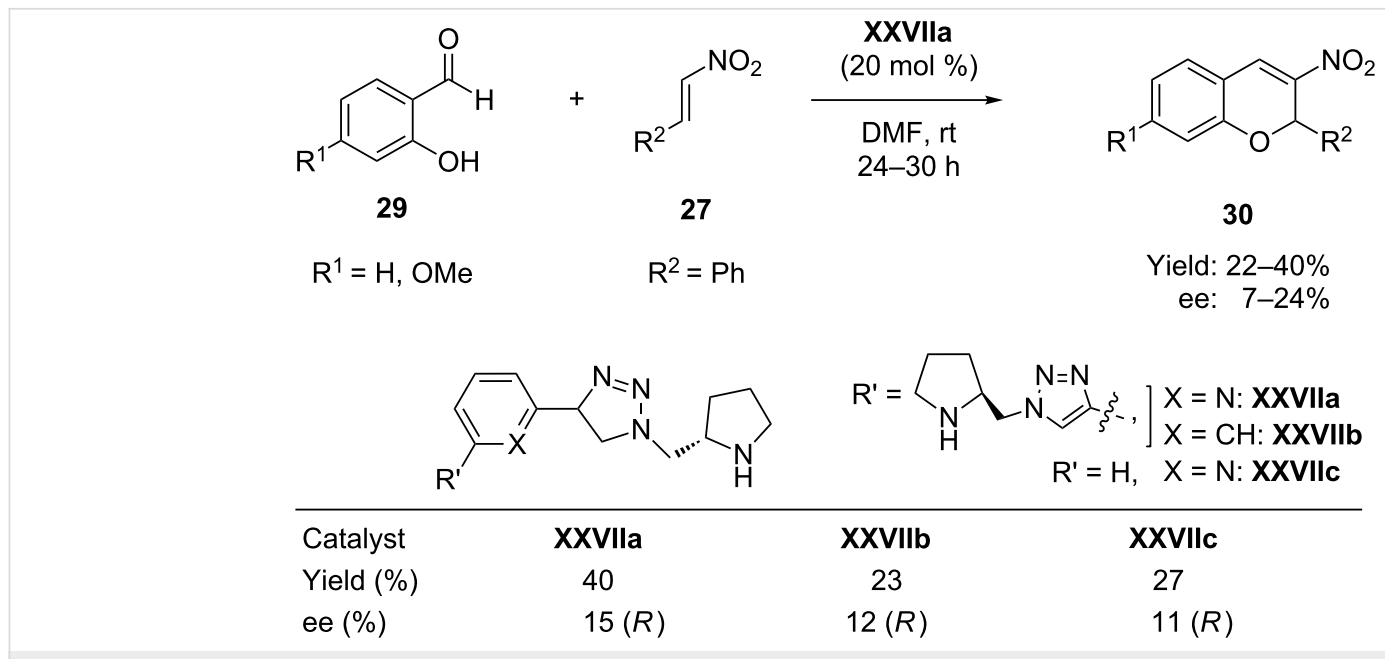

Scheme 15: Asymmetric synthesis of nitrochromenes from salicylaldehydes and $\beta$-nitrostyrene, as reported by Sankararaman.

the presence of L-pipecolinic acid (XLIII) as organocatalyst in toluene at $80^{\circ} \mathrm{C}$, which proceeded with high yield but poor enantioselectivity (5-17\% ee) (Scheme 16).

Very recently, Schreiner et al. [63] reported a bifunctional thiourea XXXIb catalyzed tandem reaction of salicyl$N$-tosylimines $\mathbf{3 3}$ with nitroolefins $\mathbf{2 7}$ in toluene at room temperature for the synthesis of nitrochromenes $\mathbf{2 8}$, which resulted in poor yield and good enantioselectivities. A broad range of substituted nitrostyrenes was studied for these tandem oxa-Michel-aza-Henry-desulfonamidation processes to afford the corresponding 2-aryl-3-nitro- $2 \mathrm{H}$ chromenes by a kinetically controlled desulfonamidation step (Scheme 17).

\section{Organocatalytic thio-Michael reactions to access functionalized thiochromenes 2.1. Reactions of 2-mercaptobenzaldehydes with acyclic/cyclic $\alpha, \beta$-unsaturated compounds}

The organocatalytic enantioselective synthesis of chiral thiochromenes through tandem/domino-Michael addition reactions have featured in the literature of the past few years. In 2006, Wang et al. [64] first reported a very straightforward and effective method for the one-pot enantioselective synthesis of chiral $2 \mathrm{H}$-thiochromene-3-carbaldehydes 35 through the reaction of 2-mercaptobenzaldehydes $\mathbf{3 4}$ with $\alpha, \beta$-unsaturated aldehydes $\mathbf{2}$, efficiently promoted by $(S)$-diphenylpyrrolinol silyl ether (Ia) as organocatalyst and benzoic acid as cocatalyst in toluene at room temperature (Scheme 18). The protocol<smiles>[R]c1cc([R])c(O)c(C=O)c1</smiles>

31<smiles>[R]C=[N+]([O-])[O-]</smiles>

27 $\mathrm{R}^{2}=\mathrm{Ph}$

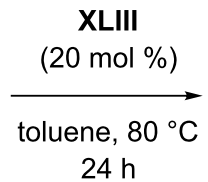

$24 \mathrm{~h}$

$\mathrm{R}^{1}=\mathrm{Cl}, \mathrm{Br}, \mathrm{OH}$

$\mathrm{R}^{3}=\mathrm{Cl}, \mathrm{H}$<smiles>[R]c1cc([R])c2c(c1)C=C([N+](=O)[O-])C([R])O2</smiles>

32

Yield: $60-81 \%$ ee: $5-17 \%$

\begin{tabular}{lccc} 
& XLIII & XLIV & XLV \\
\hline Catalyst & 81 & 68 & 30 \\
Yield (\%) & $5(R)$ & 0 & 0 \\
ee $(\%)$ & 5 XIII & & XLV
\end{tabular}

Scheme 16: Domino Michael-aldol reaction between salicyaldehydes with $\beta$-nitrostyrene, as reported by Das and co-workers. 
<smiles>Oc1c[R1]ccc1C=N[AsH3-]</smiles>

33<smiles>[R]C=C[N+](=O)[O-]</smiles>

27<smiles>[R]C1Oc2c[R17]ccc2C=C1[N+](=O)[O-]</smiles>

28

$$
\mathrm{R}^{1}=\mathrm{H}, 4-\mathrm{Br}, 5-\mathrm{OMe} \quad \mathrm{R}^{2}=\mathrm{Ph}
$$

Yield: $20-93 \%$

ee: $29-80 \%$

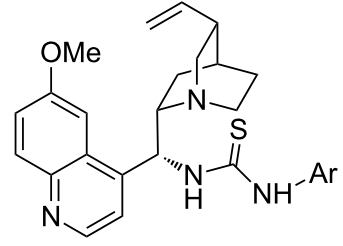

XXXla<smiles>C=CC1CC2CCC1N2C(=S)NC(=S)NC(=O)c1ccccc1</smiles>

XXXIb<smiles>C=CC1CC2CCC1N2C(O)c1ccnc2ccc(OC)cc12</smiles>

XLa<smiles>C=CC1CC2CCN1C2[C@H](O)c1ccnc2ccc(OC)cc12</smiles>

XLC

Ar: $3,5-\left(\mathrm{CF}_{3}\right) \mathrm{C}_{6} \mathrm{H}_{3}$

\begin{tabular}{lcccc}
\hline Catalyst & XXXla & XXXIb & XLa & XLc \\
Yield $(\%)$ & 0 & 65 & 0 & 53 \\
ee $(\%)$ & - & $46(R)$ & - & $11(R)$
\end{tabular}

Scheme 17: Enantioselective synthesis of 2-aryl-3-nitro-2H-chromenes, as reported by Schreiner.<smiles>O=C(O)c1cc[R17]cc1S</smiles>

34<smiles>[R]C=CC=O</smiles>

2

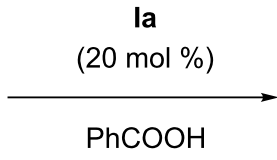

(20 $\mathrm{mol} \%)$ $\mathrm{CHCl}_{3},-15^{\circ} \mathrm{C}, 24 \mathrm{~h}$<smiles>[R2]C1Sc2c[R17]ccc2C=C1C=O</smiles>

35

ee: $91-98 \%$ dehydration

tandem

Michael-aldol<smiles>[R]C1Sc2cc[R17](I)cc2C(O)C1C(C)=O</smiles>

$\mathrm{R}^{1}=\mathrm{H}, 5-\mathrm{Cl}, 5-\mathrm{OMe}, 5-\mathrm{Me}, 3,4-(\mathrm{CH})_{4}, 4,6-(\mathrm{OMe})_{2}$

$\mathrm{R}^{2}=\mathrm{Ph}, 4-\mathrm{NC}-\mathrm{C}_{6} \mathrm{H}_{4}, 4-\mathrm{ClC}_{6} \mathrm{H}_{4}, 4-\mathrm{NO}_{2} \mathrm{C}_{6} \mathrm{H}_{4}$, COOEt, $n-\mathrm{Bu}$, propyl<smiles>[R]C([17Br])([17Br])C1CCCN1</smiles>

la: $\mathrm{Ar}=3,5-\left(\mathrm{CF}_{3}\right)_{2} \mathrm{C}_{6} \mathrm{H}_{3}$, $\mathrm{R}=\mathrm{TMS}$<smiles>O=C(O)C1CCCN1</smiles>

IX<smiles>[Al]NCC1CCCN1</smiles>

$\mathbf{X V} \mathbf{l}$<smiles>C1CNC(CN2CCCC2)C1</smiles>

$\mathbf{X I}$<smiles>CN1C(=O)C(Cc2ccccc2)NC1C(C)(C)C</smiles>

XXII

\begin{tabular}{llllll}
\hline Catalyst & la & $\mathbf{I X}$ & $\mathbf{X V}$ & $\mathbf{X I}$ & $\mathbf{X X}$ \\
Yield (\%) & 85 & 80 & 87 & 93 & $<10$ \\
ee $(\%)$ & $94(R)$ & $-10(S)$ & $-50(S)$ & 0 & -
\end{tabular}

Scheme 18: (S)-diphenylpyrrolinol silyl ether-promoted cascade thio-Michael-aldol reactions, as reported by Wang. 


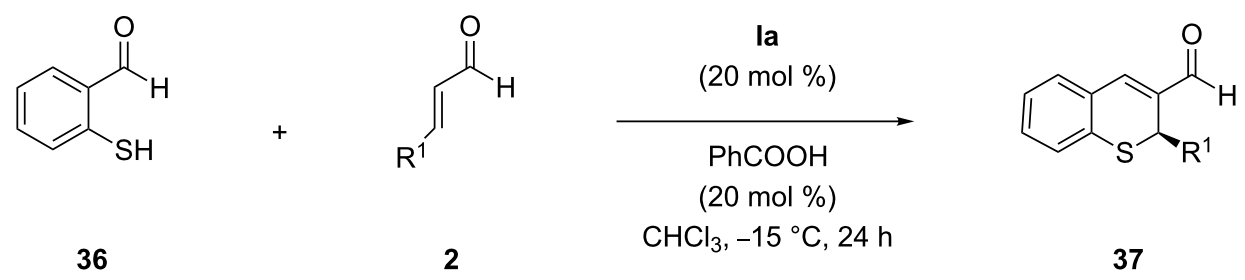

$\mathrm{R}^{1}=\mathrm{Ph}, 4-\mathrm{NC}-\mathrm{C}_{6} \mathrm{H}_{4}, 4-\mathrm{ClC}_{6} \mathrm{H}_{4}$, COOEt, $n-\mathrm{Bu}$, propyl, 4- $\mathrm{NO}_{2} \mathrm{C}_{6} \mathrm{H}_{4}$

Yield: $53-93 \%$

ee: $91-98 \%$<smiles>[R]C([17Br])([17Br])C1CCCN1</smiles>

la: $\mathrm{Ar}=3,5-\left(\mathrm{CF}_{3}\right)_{2} \mathrm{C}_{6} \mathrm{H}_{4}$ $R=T M S$

lb: $\mathrm{Ar}=\mathrm{Ph} ; \mathrm{R}=\mathrm{TMS}$

Id: $A r=2$-napthyl; $R=$ TMS<smiles>O=C(O)C1CCCN1</smiles>

IX<smiles>NC(=O)C1CCCN1</smiles>

$\mathbf{X}$<smiles>C1CNC(CN2CCCC2)C1</smiles>

$\mathbf{X} \mathbf{I}$<smiles>OCC1CCCN1</smiles>

XIV

\begin{tabular}{llllllll}
\hline Catalyst & la & lb & Id & IX & $\mathbf{X}$ & $\mathbf{X I}$ & XIV \\
Yield (\%) & 74 & 95 & 71 & 87 & 11 & 86 & 91 \\
ee (\%) & $98(R)$ & $55(R)$ & $79(R)$ & $-7(S)$ & $2(R)$ & $7(R)$ & $-22(S)$
\end{tabular}

Scheme 19: Organocatalytic asymmetric domino Michael-aldol condensation of mercaptobenzaldehyde and $\alpha, \beta$-unsaturated aldehydes, as developed by Córdova.

provides good yield and high enantioselectivity of the desired products. The yield of the reactions does not reduce appreciably when substituents are present on the aromatic rings of the mercaptobenzaldehydes. Mechanistically, the reaction proceeds in a tandem thio-Michael-aldol reaction through the formation of active iminium species.

Almost at the same time Córdova et al. [65] developed a similar protocol for enantioselective synthesis of pharmaceutically valuable $2 H$-1-benzothiopyrans 37 using the closely related catalyst Ia through the same iminium-enamine activation mode of the $\alpha, \beta$-unsaturated aldehydes 2 . The asymmetric domino reactions proceeded with high yields (53-93\%) and with excellent chemo- and stereoselectivities (up to $98 \%$ ee) in chloroform as solvent (Scheme 19). The analogous catalysts also show similar results under the same conditions after long reaction times.

The same group [66] further presented a simple organocatalytic synthesis of tetrahydrothioxanthenones, derivatives of thiochromene. The catalytic domino thia-Michael-aldol reaction of 2-mercaptobenzaldehydes $\mathbf{3 6}$ and $\alpha, \beta$-unsaturated cyclic ketones 38 proceeded in a highly chemoselective fashion, furnishing the corresponding products $\mathbf{3 9}$ in high yield and with moderate to good ee. The mechanism proposed involves the same iminium activation (Scheme 18) of the $\alpha, \beta$-unsaturated cyclic ketones by the chiral pyrrolidine derivatives XIV (Scheme 20).

In 2007 Wang et al. [67] presented a hydrogen-bond-mediated catalysis in order to perform highly enantio- and diastereoselective tandem Michael-aldol reactions for the synthesis of thiochromene derivatives. In a very low catalyst loading $(<1$ mol \%) of hybrid thiourea-cinchona bifunctional chiral organocatalyst XXXIb, the reaction of 2-mercaptobenzaldehydes 34 and $\alpha, \beta$-unsaturated oxazolidinones $\mathbf{4 0}$ by a synergistic noncovalent hydrogen-bonding dual-activation strategy afforded the highly chiral thiochromenes $\mathbf{4 1}$ with excellent yields and enantioselectivities (Scheme 21). The change of aldehyde group in the $\alpha, \beta$-unsaturated system to a carboxylic 


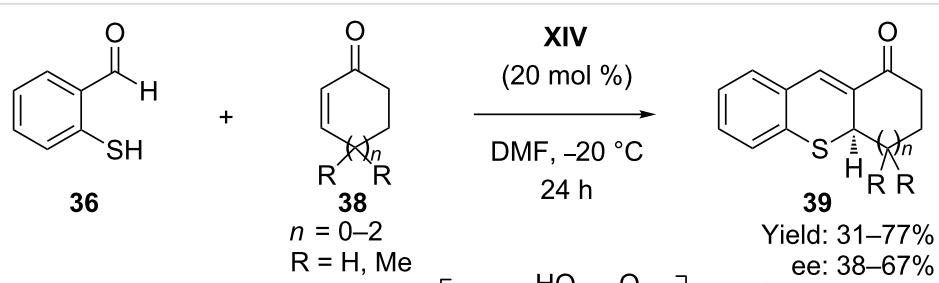

Michael-aldol
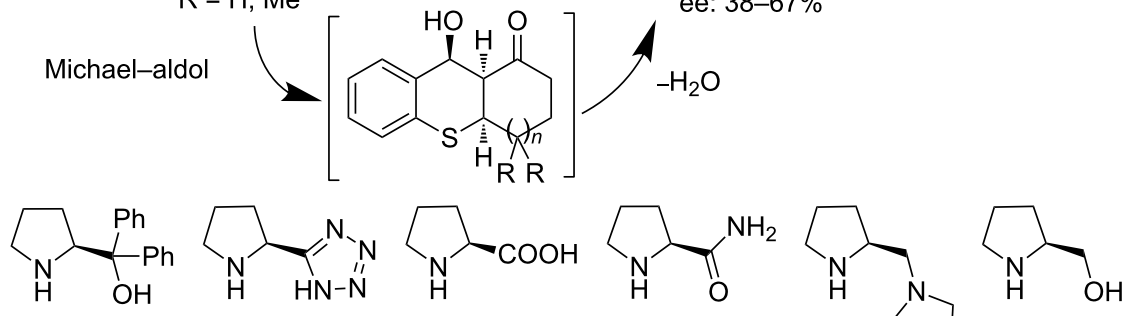

\begin{tabular}{lccllll} 
& Ic & $\mathbf{V}$ & $\mathbf{I X}$ & $\mathbf{X}$ & $\mathbf{X I}$ & $\mathbf{X I V}$ \\
\hline Catalyst & Ic & $\mathbf{V}$ & $\mathbf{I X}$ & $\mathbf{X}$ & $\mathbf{X I}$ & $\mathbf{X I V}$ \\
Yield $(\%)$ & 0 & trace & 40 & 58 & 74 & 74 \\
ee $(\%)$ & - & - & $30(R)$ & $39(R)$ & $52(R)$ & $62(R)$
\end{tabular}

Scheme 20: Organocatalytic asymmetric domino Michael-aldol condensation between mercaptobenzaldehyde and $\alpha, \beta$-unsaturated cyclic ketones, as presented by Córdova and co-workers.<smiles>O=Cc1cc[R1]cc1S</smiles>

34<smiles>[R]C=CC(=O)N1CCCC1=O</smiles>

40

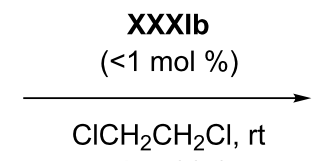

dr: $>20: 1$<smiles>[R2]C1SC2=C(C=C[R17]C=C2)[C@H](O)[C@@H]1C(=O)N1CCOC1=O</smiles>

41

ee: $91-99 \%$

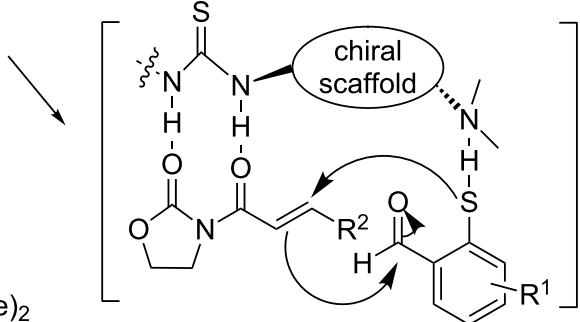

$\mathrm{R}^{1}=\mathrm{H}, 5-\mathrm{Me}, 5-\mathrm{Cl}, 4,6-(\mathrm{Me})$

$\mathrm{R}^{2}=\mathrm{Ph}, 4-\mathrm{ClC}_{6} \mathrm{H}_{4}, 4-\mathrm{OMeC}_{6} \mathrm{H}_{4}, 3-\mathrm{MeC}_{6} \mathrm{H}_{4}$, 3-thienyl<smiles>CCNC(=S)Nc1ccc2ccccc2c1-c1c(N(C)C)ccc2ccccc12</smiles>

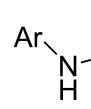<smiles>C=CC1CN2CCC1CN2Cc1ccccc1</smiles>

XXVIII<smiles>CN(C)C1CCCCC1NC(=S)NC(=S)N1c2ccccc21</smiles>

XXIX

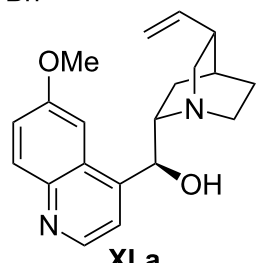<smiles>C=CC1CC2CCC1N2C(=S)NC(=S)NC(=O)c1cccc(Cl)c1</smiles>

XXXIb

$$
\text { Ar: } 3,5-\left(\mathrm{CF}_{3}\right) \mathrm{C}_{6} \mathrm{H}_{3} \quad \text { XXXXII }
$$

\begin{tabular}{lcllll}
\hline Catalyst & XXXIII & $\mathbf{X X I X}$ & $\mathbf{X X X I b}$ & $\mathbf{X X X V I I}$ & $\mathbf{X L a}$ \\
Yield $(\%)$ & 90 & 85 & 90 & 93 & 92 \\
ee $(\%)$ & 0 & $-82(2 S, 3 R, 4 S)$ & $99(2 R, 3 R, 4 S)$ & $-94(2 S, 3 R, 4 S)$ & $-60(2 S, 3 R, 4 S$
\end{tabular}

Scheme 21: Hydrogen-bond-mediated Michael-aldol reaction of 2-mercaptobenzaldehyde with $\alpha, \beta$-unsaturated oxazolidinones, as presented by Wang and co-workers. 
acid derivative enables the process to be activated by hydrogen bonding rather than covalent interactions, which prevents the undesirable dehydration process.

Subsequently, the same researchers [68] reported a synthesis of bioactive succinimide-containing benzothiochromenes by condensation of 2-mercaptobenzaldehydes $\mathbf{3 4}$ with maleimides $\mathbf{4 2}$ catalyzed by a bifunctional chiral amine thiourea XXXVII. Mechanistically, the reaction proceeded through a hydrogenbond-mediated activation mechanism by using $1 \mathrm{~mol} \%$ catalyst loading, which afforded versatile succinimide-containing benzothiopyrans $\mathbf{4 3}$ with the generation of three stereocenters in one single operation (Scheme 22). The method provides a general approach to the preparation of a range of substituted<smiles>O=Cc1cc[R1]cc1S</smiles>

34<smiles>[R]N1C(=O)C=CC1=O</smiles>

42

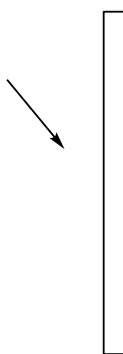

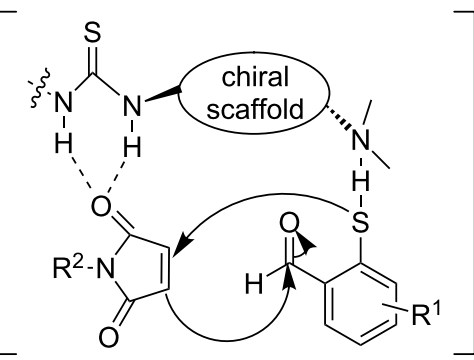

XXXVII

$(1 \mathrm{~mol} \%)$

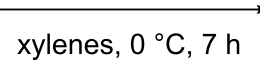

ee: $74-94 \%$

$\mathrm{R}^{1}=4-\mathrm{Me}, 5-\mathrm{Me}, 4-\mathrm{Cl}$

$\mathrm{R}^{2}=\mathrm{Ph}, 4-\mathrm{OMeC}_{6} \mathrm{H}_{4}, 4-\mathrm{BrC}_{6} \mathrm{H}_{4}, \mathrm{Bn}, 3,5-(\mathrm{Me})_{2} \mathrm{C}_{6} \mathrm{H}_{3}$<smiles>CNC(=S)Nc1ccc2ccccc2c1-c1c(N(C)C)ccc2ccccc12</smiles>

XXVIII<smiles>CN(C)C1CCCCC1NC(=S)N[Al]</smiles>

XXXVII<smiles>C=CC1CC2CCN1C(Cc1ccccc1)C2c1ccnc2ccc(NC(=S)NC3CCCCC3)cc12</smiles>

XXIX<smiles>C=CC1CC2CCN1CC2[C@H](O)c1ccnc2ccc(OC)cc12</smiles>

XLa<smiles>C=CC1CC2CCC1N2SC(=S)NC1CCCCC1</smiles>

XXXIb<smiles>C=CC1CC2CC1CN2C(Oc1cc2ccccc2c2ccccc12)c1ccnc2ccc(O)cc12</smiles>

XLb

Ar: $3,5-\left(\mathrm{CF}_{3}\right) \mathrm{C}_{6} \mathrm{H}_{3}$

\begin{tabular}{lclllll}
\hline Catalyst & XXVIII & XXIX & XXXIb & XXXVII & XLa & XLb \\
Yield $(\%)$ & 75 & 85 & 82 & 94 & 90 & 90 \\
ee $(\%)$ & - & $-33(2 R, 3 R, 4 S)$ & $-42(2 R, 3 R, 4 S)$ & $70(2 S, 3 S, 4 R)$ & $-47(2 R, 3 R, 4 S)$ & $-23(2 R, 3 R, 4 S$.
\end{tabular}


benzothiopyrans containing three stereocenters, with high enantiomeric excess (74-94\% ee) and good to high levels of diastereoselectivities $(3: 1$ to $20: 1)$.

In 2008 Córdova et al. [69] developed a novel tandem reaction between 2-mercaptoacetophenone $\mathbf{4 4}$ and $\alpha, \beta$-unsaturated aldehydes $\mathbf{2}$ promoted by TMS-protected prolinol Ia as organocatalyst in the presence of 2-nitrobenzoic acid additive (Scheme 23). Avoiding the dehydration step, it is possible by this protocol to obtain thiochromans $\mathbf{4 5}$ bearing three contiguous stereocenters and a tertiary aldol structural motif with excellent enantioselectivities (96-99\% ee) and yields (71-98\%), and with good diastereocontrol (10:1 to $15: 1 \mathrm{dr}$ )

In the same year Zhao et al. [70] reported an efficient synthesis of highly functionalized thiochromans having three chiral centers, using a tandem thio-Michael-Henry reaction of 2-mercaptobenzaldehydes 34 with $\beta$-nitrostyrenes $\mathbf{4 6}$ and using cupreine XXXIXa as catalyst in anhydrous diethyl ether. The protocol afforded the corresponding thiochroman 47 with excellent enantioselectivities and moderate diastereoselectivities (Scheme 24). A single recrystallization of the diastereomeric mixture from hexane/EtOAc enhances both the enantioselectivities (up to $>99 \%$ ee) and diastereoselectivities (up to $98 \%$ de).

Later on the same group [71] developed another hydrogenbond-mediated catalysis for the synthesis of tetrasubstituted thiochromans having three continuous stereocenters 49 following domino thio-Michael-Knoevenagel reaction between 2-mercaptobenzaldehydes 34 and benzylidenemalonates 48 using quinine thiourea XXXIIa as catalyst (Scheme 25). The steric and electronic environments of the substrates were found to affect profoundly the stereoselectivities of the reaction. It was observed that the diastereoselectivity of the reaction increased if there was a substituent at the ortho-position of the phenyl ring of the benzylidene moiety, while the enantioselectivity of the reaction decreased if the phenyl ring was substituted with an<smiles>O=Cc1ccccc1S</smiles>

44<smiles>[R]C=CC=O</smiles>

2

la

$(20 \mathrm{~mol} \%)$

2-nitrobenzoic acid

(20 mol \%)

toluene, $-25^{\circ} \mathrm{C}$

$64 \mathrm{~h}$<smiles>[R]C1Sc2ccccc2[C@@](C)(O)C1C=O</smiles>

45

Yield: $71-98 \%$

ee: $96-99 \%$

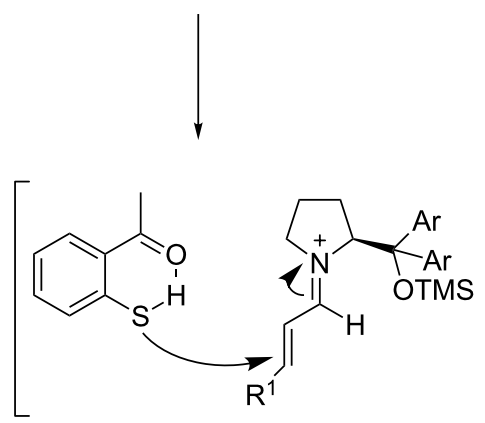

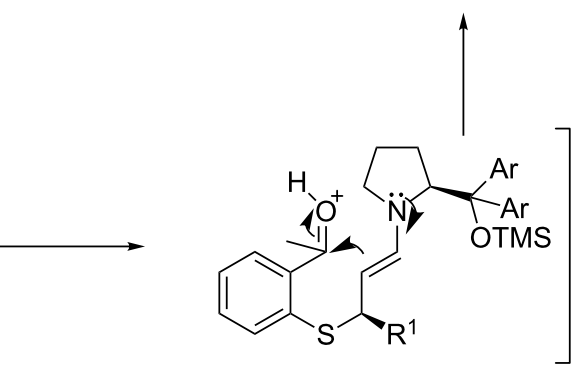

$\mathrm{R}^{1}=\mathrm{Ph}, 4-\mathrm{CNC}_{6} \mathrm{H}_{4}, 4-\mathrm{ClC}_{6} \mathrm{H}_{4}, 4-\mathrm{BrC}_{6} \mathrm{H}_{4}$, 2-naphthyl, COOEt, $n-\mathrm{Bu}, 4-\mathrm{NO}_{2} \mathrm{C}_{6} \mathrm{H}_{4}$<smiles>[Al]C([Al])(O[Te])C1CCCN1</smiles>

la

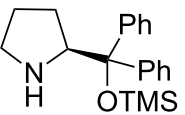

Ib<smiles>OC(c1ccccc1)(c1ccccc1)C1CCCN1</smiles>

Ic<smiles>O=C(O)C1CCCN1</smiles>

IX

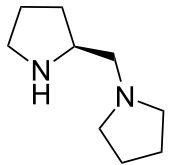

$\mathbf{X I}$

$\mathrm{Ar}=3,5-\left(\mathrm{CF}_{3}\right) \mathrm{C}_{6} \mathrm{H}_{3}$

\begin{tabular}{llllll}
\hline Catalyst & la & Ib & Ic & IX & $\mathbf{X I}$ \\
Yield $(\%)$ & 98 & 46 & trace & 54 & 44 \\
ee $(\%)$ & $97(2 S, 3 R, 4 S)$ & $38(2 S, 3 R, 4 S)$ & - & $5(2 S, 3 R, 4 S)$ & $3(2 S, 3 R, 4 S$
\end{tabular}


<smiles>O=Cc1cc[R17]cc1S</smiles>

34<smiles>[R]c1ccccc1/C=C/[N+](=O)[O-]</smiles>

46

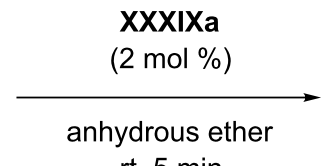
$\mathrm{rt}, 5 \mathrm{~min}$

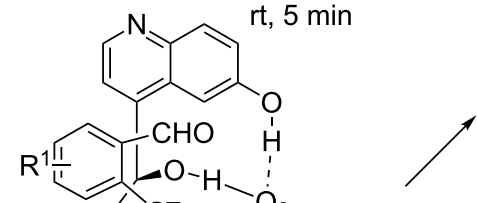<smiles>[R][R]1ccc(C2Sc3c[R17]ccc3C(O)C2[N+](=O)[O-])cc1</smiles>

Yield: $84-97 \%$ ee: $85-99 \%$ $\mathrm{R}^{2}=\mathrm{H}, 2-\mathrm{OMe}, 2-\mathrm{NO}_{2}, 2-\mathrm{OMe}, 4-\mathrm{Br}$<smiles>[R10]Oc1ccc2nccc(C([R10])C3CC4CCN3C4)c2c1</smiles>

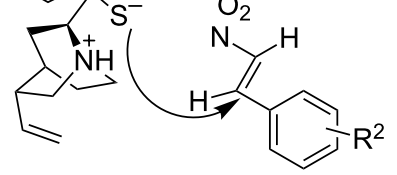

XXXIXa: $\mathrm{R}^{1}=\mathrm{H}, \mathrm{R}^{2}=\mathrm{H}$

XXXIXb: $R^{1}=H, R^{2}=M e$

XXXIXc: $R^{1}=B n, R^{2}=H$

\begin{tabular}{|c|c|c|c|}
\hline Catalyst & XXXIXa & XXXIXb & XXXIXc \\
\hline Conversion (\%) & 55 & 100 & 100 \\
\hline ee $(\%)$ & $99(2 R, 3 S, 4 R)$ & $8(2 R, 3 S, 4 R)$ & $29(2 R, 3 S, 4 R)$ \\
\hline
\end{tabular}

Scheme 24: Enantioselective tandem Michael-Henry reaction of 2-mercaptobenzaldehyde with $\beta$-nitrostyrenes reported by Zhao.<smiles>O=Cc1cc[R1]cc1S</smiles>

34<smiles>[R]C=C(OCC)C(=O)OCC</smiles>

48

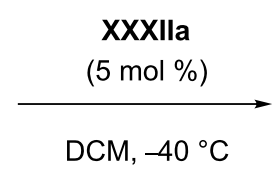

$2 \mathrm{~h}$

$\mathrm{R}^{1}=\mathrm{H}, 4-\mathrm{OMe}, 4-\mathrm{Cl}$

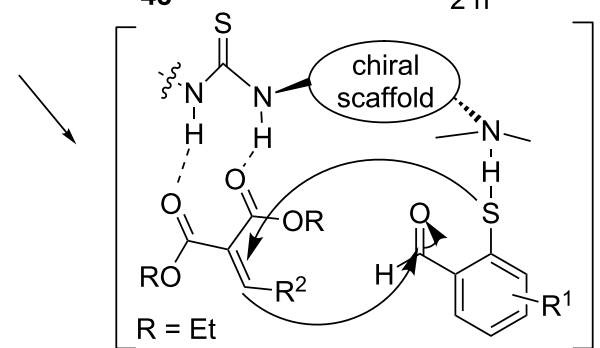

$\mathrm{R}^{2}=2-\mathrm{Me}-3-\mathrm{OMeC}_{6} \mathrm{H}_{3}, 2-\mathrm{Me}-3-\mathrm{OBnC}_{6} \mathrm{H}_{3}, 3-\mathrm{Br}-2-\mathrm{Me}_{6} \mathrm{C}_{6} \mathrm{H}_{3}, 2-\mathrm{Me}-3-\mathrm{NO}_{2} \mathrm{C}_{6} \mathrm{H}_{3}$<smiles>C=CN1C2CCC1C([C@H](NC(=S)NC1CCCCC1)c1ccnc3ccc(OC)cc13)C2</smiles>

XXXIla

$\mathrm{Ar}=3,5-\left(\mathrm{CF}_{3}\right)_{2} \mathrm{C}_{6} \mathrm{H}_{3}$<smiles>[R20]Oc1ccc2nccc(C([R9])C3CC4CCN3C4)c2c1</smiles>

XXXIXa: $R^{1}=H, R^{2}=H$

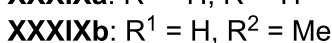

XXXIXc: $R^{1}=B n, R^{2}=H$

\begin{tabular}{|c|c|c|c|c|}
\hline \multicolumn{2}{|c|}{$\mathrm{Ar}=3,5-\left(\mathrm{CF}_{3}\right)_{2} \mathrm{C}_{6} \mathrm{H}_{3}$} & \multicolumn{3}{|c|}{ 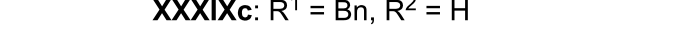 } \\
\hline Catalyst & XXXIb & XXXIXa & $\mathbf{X X X I X b}$ & XXXIXc \\
\hline Conversion (\%) & 94 & 90 & 86 & 81 \\
\hline ee $(\%)$ & $88(2 R, 4 R)$ & $14(2 R, 4 R)$ & $23(2 R, 4 R)$ & $6(2 R, 4 R)$ \\
\hline
\end{tabular}

Scheme 25: Enantioselective tandem Michael-Knoevenagel reaction between 2-mercaptobenzaldehydes and benzylidenemalonates, as developed by the Zhao group. 
electron-withdrawing group. The best result, with yields up to $96 \%$ and enantioselectivities up to $96 \%$, was obtained in DCM solvent at $-40{ }^{\circ} \mathrm{C}$.

An unprecedented asymmetric domino thio-Michael-Michael process, involving dynamic kinetic resolution, was reported by Wang et al. [72] using cinchona alkaloid amine-thiourea XXXIb as catalyst at a low catalytic loading of $2 \mathrm{~mol} \%$. Reaction of 3-(2-mercaptophenyl)-2-propenoic acid ethyl esters $\mathbf{5 0}$ with $\alpha, \beta$-unsaturated nitro compounds $\mathbf{2 7}$ in toluene afforded chiral thiochromans $\mathbf{5 1}$ bearing three continuous stereogenic centers with high diastereo- and enantioselectivities by this novel cascade process (Scheme 26).

\section{Organocatalytic aza-Michael reactions to access functionalized 1,2-dihydroquinolines}

\subsection{Reaction of 2-aminobenzaldehydes with acyclic} $\alpha, \beta$-unsaturated compounds

The asymmetric organocatalytic Michael conjugate addition of an amine to an electron-deficient $\alpha, \beta$-unsaturated system provides a unique reaction process because of the weaker nucleophilic character of the amine compared to a thiol or an alcohol. Córdova and co-workers [73] in 2007 first reported an asymmetric organocatalytic tandem aza-Michael-aldol reaction for the synthesis of 1,2-dihydroquinolines through the iminium activation strategy. Thus, the aza-Michael-aldol reaction between 2-aminobenzaldehydes $\mathbf{5 2}$ and enals $\mathbf{2}$ in the presence of diphenylprolinol trimethylsilyl ether $\mathbf{I b}$ as catalyst and benzoic acid as additive, provides 1,2-dihyroquinolines 53 with high yields (90\%) and high ee (>99\%) (Scheme 27). Various enal substituents, such as aryl, alkyl and ester groups, are readily tolerated in the reaction. However, with $\beta$-alkyl $\alpha, \beta$-unsaturated aldehydes the highest asymmetric induction was achieved in $\mathrm{CH}_{3} \mathrm{CN}$ without addition of an organic acid.

Subsequently, Wang and co-workers [74] reported a similar aza-Michael-aldol sequence employing more nucleophilic $\mathrm{N}$-protected 2-aminobenzaldehydes in a basic medium as Michael donor for the construction of 1,2-dihydroquinoline derivatives. In their protocol, the reaction of 2-N-protected aminobenzaldehydes $\mathbf{5 4}$ with $\alpha, \beta$-unsaturated aldehydes $\mathbf{2}$ promoted by $(S)$-diphenylprolinol TES ether Ie in the presence of NaOAc afforded the pharmaceutically valuable chiral 1,2dihydroquinolines $\mathbf{5 5}$ with good yield (98\%) and excellent ee (>96\%) (Scheme 28$)$. The reaction yield was dramatically improved in the presence of $\mathrm{NaOAc}$ and $4 \AA \mathrm{MS}$, without sacrificing enantioselectivity. The mechanistic study revealed that the conjugate-addition-aldol-dehydration sequence passes through the enamine intermediate. A wide range of readily available Michael acceptor $\alpha, \beta$-unsaturated aldehydes are tolerated in the reaction. The protection group of the amino function also governs both reactivity and enantioselectivity. The Cbzprotected aminobenzaldehydes in dichloroethane afford the best results in a shorter reaction time.<smiles>CCOC(=O)/C=C/c1cc[R1]cc1S</smiles>

50<smiles>[R]C=C[N+](=O)[O-]</smiles>

27

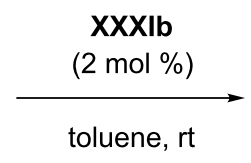

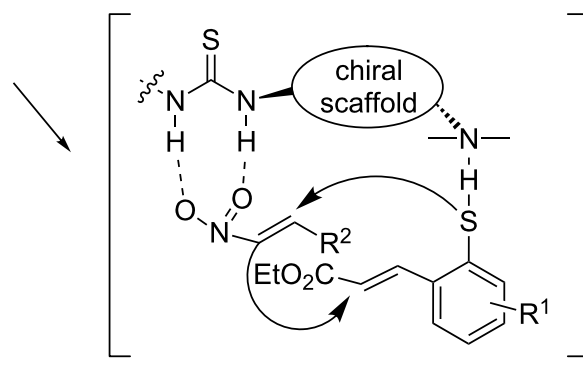

$\mathrm{R}^{1}=\mathrm{H}, 4-\mathrm{Me}, 4-\mathrm{OMe}, 4-\mathrm{Cl}$

$\mathrm{R}^{2}=\mathrm{Ph}, 4-\mathrm{BnO}, 4-\mathrm{OMeC}_{6} \mathrm{H}_{4}, 2-\mathrm{OMeC}_{6} \mathrm{H}_{4}$, thiophen-2-yl<smiles>[R]C1SC2=C(C=C[R1]C=C2)C(CC(=O)OCC)C1[N+](=O)[O-]</smiles>

51 ee: $92-99 \%$

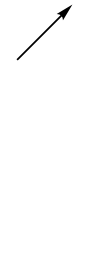<smiles>C=CC1CC2CCC1N2C(=S)NC(=S)NC(=O)c1ccccc1</smiles>

XXXIb

$\mathrm{Ar}=3,5-\left(\mathrm{CF}_{3}\right)_{2} \mathrm{C}_{6} \mathrm{H}_{3}$ 


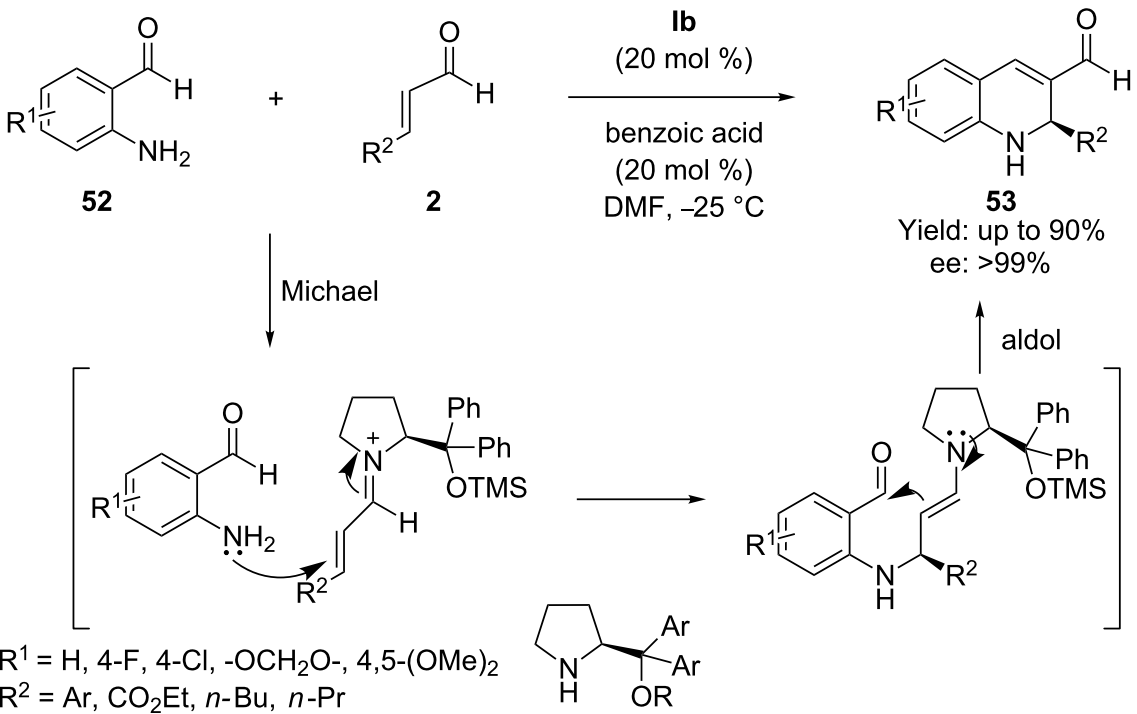

$\mathrm{R}^{2}=\mathrm{Ar}, \mathrm{CO}_{2} \mathrm{Et}, n-\mathrm{Bu}, n-\mathrm{Pr}$

la: $\mathrm{Ar}=3,5-\left(\mathrm{CF}_{3}\right)_{2} \mathrm{C}_{6} \mathrm{H}_{3}, \mathrm{R}=\mathrm{TMS}$

lb: $\mathrm{Ar}=\mathrm{Ph}, \mathrm{R}=\mathrm{TMS}$

Id: $A r=2$-naphthyl, $R=T M S$

\begin{tabular}{llll}
\hline Catalyst & la & lb & Id \\
Yield (\%) & $<2$ & 67 & 44 \\
ee $(\%)$ & - & $88(R)$ & $82(R)$
\end{tabular}

Scheme 27: Domino aza-Michael-aldol reaction between 2-aminobenzaldehydes and $\alpha, \beta$-unsaturated aldehydes, as reported by Córdova and co-workers.<smiles>O=Cc1cc[R1]cc1NP</smiles>

54

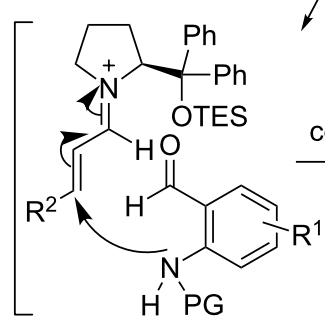

$R e$ face addition

$$
\begin{aligned}
& \mathrm{R}^{1}=\mathrm{H}, 5-\mathrm{Cl}, 4,5-(\mathrm{OMe})_{2} \\
& \mathrm{R}^{2}=\text { substituted aryls } \\
& \mathrm{PG}=\mathrm{Cbz}
\end{aligned}
$$<smiles>[R]C=CC=O</smiles>

2

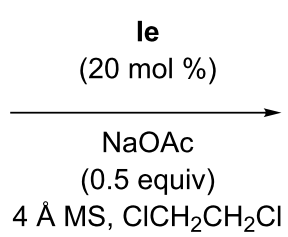

$4 \AA \mathrm{MS}, \mathrm{ClCH}_{2} \mathrm{CH}_{2} \mathrm{Cl}$<smiles>[R]C1C(C=O)=Cc2cc[R1]([H])cc2N1[R6]</smiles>

55 Yield: $98 \%$

\section{conjugate addition}

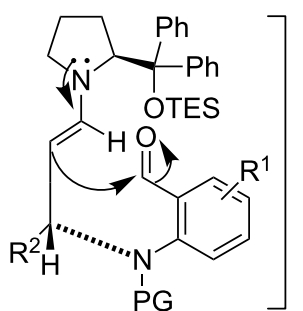

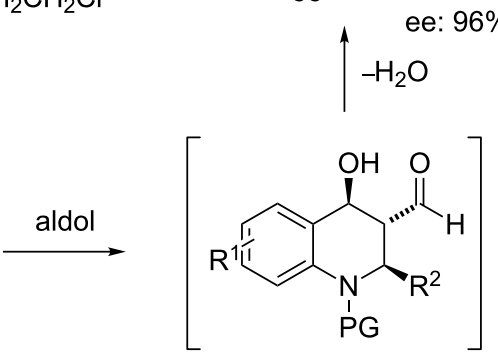

$\mathrm{Ar}=3,5-\left(\mathrm{CF}_{3}\right)_{2} \mathrm{C}_{6} \mathrm{H}_{3}, \mathrm{R}=\mathrm{TMS}$

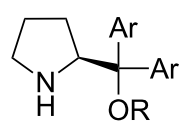

lb: $A r=P h, R=T M S$

le: $\mathrm{Ar}=\mathrm{Ph}, \mathrm{R}=\mathrm{TES}$

If: $A r=P h, R=T B S$

\begin{tabular}{lllll}
\hline Catalyst & la & lb & le & If \\
Yield (\%) & $<5$ & 71 & 95 & 68 \\
ee $(\%)$ & - & $94(R)$ & $95(R)$ & $94(R)$
\end{tabular}

Scheme 28: (S)-Diphenylprolinol TES ether-promoted aza-Michael-aldol cascade reaction, as developed by Wang's group. 


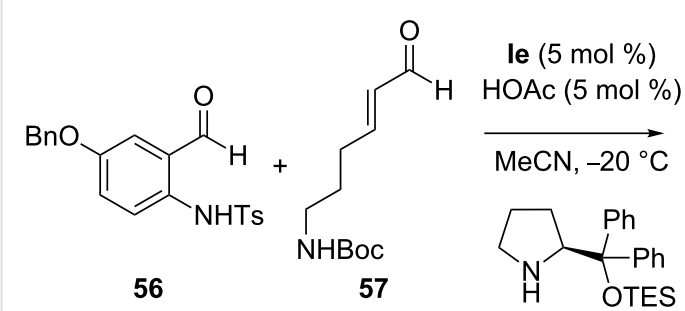

le<smiles>[3H]N1c2ccc(OCc3ccccc3)cc2C=C(C=O)[C@@H]1CCCNC(=O)C#CC</smiles>

58

Yield: quantitative ee: $95.7 \%$<smiles>NCCC[C@H]1Nc2ccc(OCc3ccccc3)cc2C2NCCC21</smiles>

59

Core structure of martinelline

Scheme 29: Domino aza-Michael-aldol reaction reported by Hamada.

By taking advantage of the above methodology, Hamada et al. [75] in 2008 reported a similar type of reaction for the construction of the 1,2-dihydroquinoline chiral core of martinelline (a nonpeptide bradykinin receptor antagonist) and its diastereoisomer. Using a domino aza-Michael-aldol reaction as the key step, reaction of aldehyde 56 with $\alpha, \beta$-unsaturated aldehyde $\mathbf{5 7}$, catalyzed by chiral prolinol ethers Ie/HOAc in acetonitrile, provided quinoline derivative $\mathbf{5 8}$ with high yield and with high enantioselectivity (Scheme 29). In contrary to the work of $\mathrm{Li}$, the presence of $4 \AA$ MS had a negative effect on the yield, whereas addition of $\mathrm{NaOAc}$ did not alter the yield and enantioselectivity. On the other hand the addition of HOAc was found to enhance the catalytic activity of Ie by increasing the yield of reaction without the loss of enantioselectivity.
In $2009 \mathrm{Xu}$ et al. [76] reported the first organocatalytic enantioselective domino aza-Michael-Henry reaction of 2-aminobenzaldehydes 54 and aromatic/aliphatic nitro olefins 27, catalyzed by bifunctional thiourea catalyst XXXVIa in benzoic acid, to generate synthetically versatile 3-nitro-1,2-dihydroquinolines 61. Synergistic activation of both reactants through stereoselective covalent activation and hydrogen-bond interaction allowed this transformation to take place under mild reaction conditions (propanol as solvent at room temperature) and afforded dihydronitroquinoline derivatives $\mathbf{6 1}$ with moderate yields and moderate to good enantioselectivities (Scheme 30).

In 2010 a cascade aza-Michael-Henry dehydration process catalyzed by quinidine-derived tertiary amine-thiourea catalyst<smiles>[R]C=C[N+](=O)[O-]</smiles>

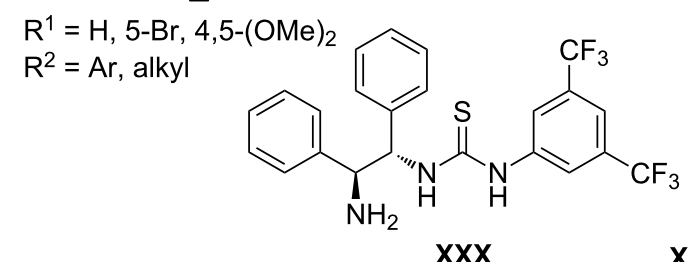

$\mathbf{X X X}$

XXXVla: $\operatorname{Ar}=(S)$-1-phenylethyl XXXVIb: $A r=(S)-1-($ naphthyl)ethyl<smiles>[R]N[C@@H]1CCCC[C@H]1NC(=S)Nc1cc(C(F)(F)F)cc(C(F)(F)F)c1</smiles>

XXXVIIIa: $\mathrm{R}^{1}=\mathrm{H}$ XXXVIIIb: $\mathrm{R}^{1}=\mathrm{CH}_{3}$

\begin{tabular}{lccccc}
\hline Catalyst & XXX & XXXVla & XXXVIb & XXXVIIIa & XXXVIIIb \\
Conversion (\%) & 37 & 70 & 51 & 60 & 51 \\
ee $(\%)$ & $12(S)$ & $85(S)$ & $86(S)$ & $75(S)$ & $5(S)$
\end{tabular}


was developed by Lu et al. [77] for the one-step preparation of chiral 3-nitro-1,2-dihydroquinolines through the installation of suitable electron withdrawing groups at the amino function of aniline. Thus the condensation of N-protected aminobenzaldehydes $\mathbf{6 2}$ with substituted nitroolefins $\mathbf{2 7}$ mediated by tertiary amine-thiourea catalyst XXXIV in toluene at room temperature afforded 3-nitro-1,2-dihydroquinolines $\mathbf{6 3}$ in high yields (92\%) and with high enantiomeric excess (90\%) (Scheme 31). In this cascade reaction, the installation of electron-withdrawing groups on the amino moiety of 2-aminobenzaldehydes is anticipated to increase the aniline $\mathrm{N}-\mathrm{H}$ acidity, the abstraction of which by the tertiary amine leads to an aza-Michael reaction. The thiourea group in the chiral catalyst is anticipated to have hydrogen-bonding interactions with the nitro group. The subsequent Henry reaction with the aldehydes, followed by dehydration, generated 3-nitro-1,2-dihydroquinolines.<smiles>[R]c1ccc(N[SH]([R])=O)c(C(C)=O)c1</smiles>

62

\section{XXXIV}

$\mathrm{R}^{2}$ toluene, $\mathrm{rt}$

27

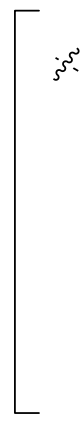<smiles>[R]c1ccc2c(c1)C=C([N+](=O)[O-])N(S([R])(=O)=O)C2[R]</smiles>

63

Yield: $75-92 \%$ ee: $70-90 \%$

$\mathrm{R}=\mathrm{H}, \mathrm{Cl}$
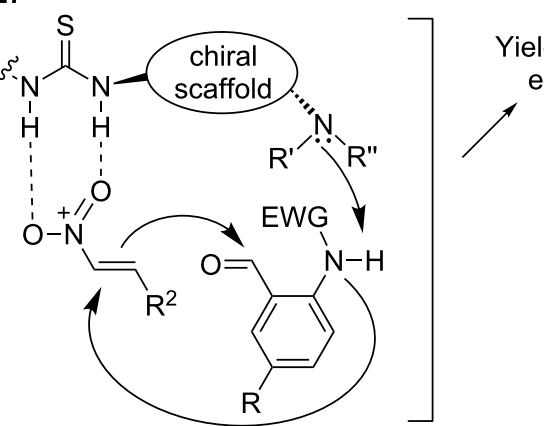

$\mathrm{R}^{1}=2,4,6-(\mathrm{iPr})_{3} \mathrm{C}_{6} \mathrm{H}_{2}, 2,4,6-(\mathrm{Me})_{3} \mathrm{C}_{6} \mathrm{H}_{2}, 3,5-\left(\mathrm{CF}_{3}\right)_{2} \mathrm{C}_{6} \mathrm{H}_{3}, 4-\mathrm{MeC}_{6} \mathrm{H}_{4}, 4-\left(\mathrm{CF}_{3}\right) \mathrm{C}_{6} \mathrm{H}_{4}, 4-\mathrm{CNC}_{6} \mathrm{H}_{4}, 4-\mathrm{NO}_{2} \mathrm{C}_{6} \mathrm{H}_{4}$, 1-naphthy $\mathrm{R}^{2}=\mathrm{Ph}, 4-\mathrm{BrC}_{6} \mathrm{H}_{4}, 4-\mathrm{FC}_{6} \mathrm{H}_{4}, 4-\mathrm{CNC}_{6} \mathrm{H}_{4}, 4-\mathrm{MeC}_{6} \mathrm{H}_{4}, 4-\mathrm{OMeC}_{6} \mathrm{H}_{4}, 3-\mathrm{ClC}_{6} \mathrm{H}_{4}, 3-\mathrm{BrC}_{6} \mathrm{H}_{4}, \mathrm{Pr}$, 1-naphthyl<smiles>CNC(=S)NC(c1ccnc2ccc(OC)cc12)C1CC2CCN1CC2</smiles>

XXXIIb: $\mathrm{Ar}=3,5-\left(\mathrm{CF}_{3}\right)_{2} \mathrm{C}_{6} \mathrm{H}_{3}$<smiles>COc1ccc2nccc(C(O)C3CC4CCN3C4)c2c1</smiles>

XXXIXd<smiles>COc1ccc2nccc([C@H](NC(=S)Nc3ccccc3O)[C@H]3CC4CCN(C4)C3)c2c1</smiles>

XXXIII<smiles></smiles>

XXXIV<smiles>COc1ccc2nccc(C(NC(=S)NC(c3ccccc3)C(O)c3ccccc3)C3CC4C=CCN3C4)c2c1</smiles>

XXV<smiles></smiles>

XLI<smiles>COc1ccc2nccc(C([18OH])N3CC4CCC3C4)c2c1</smiles>

XLII

\begin{tabular}{lccccccc}
\hline Catalyst & XXXIIb & XXXIII & XXXIV & XXXV & XXXIXd & XLI & XLII \\
Conversion(\%) & 95 & 80 & 81 & 70 & 37 & 95 & - \\
ee $(\%)$ & $23(S)$ & $9(S)$ & $90(S)$ & $15(S)$ & $12(S)$ & $13(S)$ & -
\end{tabular}




\section{Conclusion}

The advantage of organocatalysts in asymmetric synthesis has grown tremendously since its advent, and the power of tandem/ domino/cascade-Michael addition reactions promoted by chiral organocatalysts has been intensely studied within this field. In this review, we have outlined some significant works concerning the organocatalytic enantioselective Michael addition reaction from three different points of view: The conjugate addition of hetero-centered nucleophiles to $\alpha, \beta$-unsaturated compounds; in a more complex approach through tandem/ domino/cascade-Michael reactions; and by using chiral amines as organocatalysts for the enantioselective synthesis of functionalized chiral chromenes, thiochromenes and 1,2-dihydroquinolines. Despite these impressive advances, there is plenty of room for new contributions and findings, particularly to the development of new organocatalysts that can enhance the reaction rate and enantioselectivity, and to improve the substrate scope such that unreactive Michael donors/acceptors may be used in these reactions under mild reaction conditions. Future work should be focused on the utilization of these powerful strategies for the efficient assembly of biologically interesting molecules, including natural products.

\section{Acknowledgements}

The author CB gratefully acknowledges University Grants Commission (UGC) New Delhi, India, for providing financial supports in the form of a Teacher Fellowship. Author SN thanks the Department of Science and Technology (DST), Govt. of India for providing Fast Track Grant (No- 061/2011).

\section{References}

1. Ellis, G. P.; Lockhart, I. M. The Chemistry of Heterocyclic Compounds, Chromenes, Chromanones, and Chromones; Wiley-VCH: New York, 2007; Vol. 31, pp 1-1196.

2. Horton, D. A.; Boume, G. T.; Smythe, M. L. Chem. Rev. 2003, 103, 893-930. doi:10.1021/cr020033s

3. Trenor, S. R.; Shultz, A. R.; Love, B. J.; Long, T. E. Chem. Rev. 2004, 104, 3059-3078. doi:10.1021/cr030037c

4. Coi, A.; Bianucci, A. M.; Calderone, V.; Testai, L.; Digiacomo, M.; Rapposelli, S.; Balsamo, A. Bioorg. Med. Chem. 2009, 17, 5565-5571. doi:10.1016/j.bmc.2009.06.028

5. Breschi, M. C.; Calderone, V.; Martelli, A.; Minutolo, F.; Rapposelli, S.; Testai, L.; Tonelli, F.; Balsamo, A. J. Med. Chem. 2006, 49, 7600-7602. doi:10.1021/jm061228I

6. Carter, J. S.; Devadas, B.; Talley, J. J.; Brown, D. L.; Graneto, M. J.; Rogier, D. J., Jr.; Nagarajan, S. R.; Hanau, C. E.; Hartmann, S. J.; Ludwig, C. L.; Metz, S.; Korte, D.; Bertenshaw, S. R.; Obukowicz, M. G. Substituted benzopyran analogs for the treatment of inflammation. WO 00/23433, April 27, 2000.

7. Quaglia, W.; Pigini, M.; Piergentili, A.; Giannella, M.; Gentili, F.; Marucci, G.; Carrieri, A.; Carotti, A.; Poggesi, E.; Leonardi, A.; Melchiorre, C. J. Med. Chem. 2002, 45, 1633-1643. doi:10.1021/jm011066n
8. Katritzky, A. R.; Rachwal, S.; Rachwal, B. Tetrahedron 1996, 52, 15031-15070. doi:10.1016/S0040-4020(96)00911-8

9. Witherup, K. M.; Ransom, R. W.; Graham, A. C.; Bernard, A. M.; Salvatore, M. J.; Lumma, W. C.; Anderson, P. S.; Pitzenberger, S. M.; Varga, S. L. J. Am. Chem. Soc. 1995, 117, 6682-6685. doi:10.1021/ja00130a005

10. Duda, B.; Tverdomed, S. N.; Röschenthaler, G.-V. J. Org. Chem. 2011, 76, 71-79. doi:10.1021/jo101913u

11. Zhang, X.; Zang, S.; Wang, W. Angew. Chem., Int. Ed. 2010, 49, 1481-1484. doi:10.1002/anie.200906050

12. Liu, K.; Woggon, W.-D. Eur. J. Org. Chem. 2010, 1033-1036. doi:10.1002/ejoc.200901403

13. Werner, T. F.; Sohn, D.; Johansson, R. J. Labelled Compd. Radiopharm. 2000, 43, 437-447. doi:10.1002/(SICI)1099-1344(200004)43:5<437::AID-JLCR329>3.0.CO ;2-J

14. Li, L.; Chan, T. H. Org. Lett. 2001, 3, 739-741. doi:10.1021/ol000394z 15. Chen, Y.; Zhang, Q.; Zhang, B.; Xia, P.; Xia, Y.; Yang, Z.-Y.; Kilgore, N.; Wild, C.; Morris-Natschke, S. L.; Lee, K.-H. Bioorg. Med. Chem. 2004, 24, 6383-6387. doi:10.1016/j.bmc.2004.09.038

16. Elmore, S. W.; Coghlan, M. J.; Anderson, D. D.; Pratt, J. K.; Green, B. E.; Wang, A. X.; Stashko, M. A.; Lin, C. W.; Tyree, C. M.; Miner, J. N.; Jacobson, P. B.; Wilcox, D. M.; Lane, B. C. J. Med. Chem. 2001, 44, 4481-4491. doi:10.1021/jm010367u

17. Kashiwada, Y.; Yamazaki, K.; Ikeshiro, Y.; Yamagishi, T.; Fujioka, T.; Mihashi, K.; Mizuki, K.; Cosentino, L. M.; Fowke, K.; Morris-Natschke, S. L.; Lee, K.-L. Tetrahedron 2001, 57, 1559-1563. doi:10.1016/S0040-4020(00)01144-3

18. Owolabi, O. J.; Omogbai, E. K. I. J. Diabetes Metab. 2011, 2, 159. doi:10.4172/2155-6156.1000159

19. Chen, Y.; Zhang, Q.; Zhang, B.; Xia, P.; Xia, Y.; Yang, Z.-Y.; Kilgore, N.; Wild, C.; Morris-Natschke, S. L.; Lee, K.-H. Bioorg. Med. Chem. 2004, 12, 6383-6387. doi:10.1016/j.bmc.2004.09.038

20. Gartside, S. E.; Clifford, E. M.; Cowen, P. J.; Sharp, T. Br. J. Pharmacol. 1999, 127, 145-152. doi:10.1038/sj.bjp.0702546

21. Gunatilaka, A. A. L.; Kingston, D. G. I.; Wijeratne, E. M. K.; Bandara, B. M. R.; Hofmann, G. A.; Johnson, R. K. J. Nat. Prod. 1994, 57, 518-520. doi:10.1021/np50106a013

22. Westermann, B.; Ayaz, M.; van Berkel, S. S. Angew. Chem., Int. Ed. 2010, 49, 846-849. doi:10.1002/anie.200904638

23. Núñez, M. G.; García, P.; Moro, R. F.; Díez, D. Tetrahedron 2010, 66, 2089-2109. doi:10.1016/j.tet.2009.12.045

24. Bhanushali, M.; Zhao, C.-G. Synthesis 2011, 1815-1830. doi:10.1055/s-0030-1260029

25. Xu, L.-W.; Li, L.; Shi, Z.-H. Adv. Synth. Catal. 2010, 352, 243-279. doi:10.1002/adsc.200900797

26. Alba, A.-N.; Companyo, X.; Viciano, M.; Rios, R. Curr. Org. Chem. 2009, 13, 1432-1474. doi:10.2174/138527209789055054

27. Yu, X.; Wang, W. Org. Biomol. Chem. 2008, 6, 2037-2046. doi:10.1039/B800245M

28. Grondal, C.; Jeanty, M.; Enders, D. Nat. Chem. 2010, 2, 167-168. doi:10.1038/nchem.539

29. Enders, D.; Grondal, C.; Hüttl, M. R. M. Angew. Chem., Int. Ed. 2007, 46, 1570-1581. doi:10.1002/anie.200603129

30. Pellissier, H. Tetrahedron 2006, 62, 2143-2173. doi:10.1016/j.tet.2005.10.041

31. Almaşi, D.; Alonso, D. A.; Nájera, C. Tetrahedron: Asymmetry 2007, 18, 299-365. doi:10.1016/j.tetasy.2007.01.023 
32. Tsogoeva, S. B. Eur. J. Org. Chem. 2007, 1701-1716. doi:10.1002/ejoc.200600653

33. Notz, W.; Tanaka, F.; Barbas, C. F. Acc. Chem. Res. 2004, 37, 580-591. doi:10.1021/ar0300468

34. List, B. Chem. Commun. 2006, 819. doi:10.1039/B514296M

35. Mukherjee, S.; Yang, J. W.; Hoffmann, S.; List, B. Chem. Rev. 2007, 107, 5471-5569. doi:10.1021/cr0684016

36. Jarvo, E. R.; Miller, S. J. Tetrahedron 2002, 58, 2481-2495. doi:10.1016/S0040-4020(02)00122-9

37. List, B. Tetrahedron 2002, 58, 5573-5590. doi:10.1016/S0040-4020(02)00516-1

38. Erkkilä, A.; Majander, I.; Pihko, P. M. Chem. Rev. 2007, 107, 5416-5470. doi:10.1021/cr068388p

39. Lesch, B.; Torang, J.; Vanderheiden, S.; Bräse, S. Adv. Synth. Catal. 2005, 347-562. doi:10.1002/adsc.200404239

40. Ohnemüller, U. K.; Nising, C. F.; Nieger, M.; Bräse, S. Eur. J. Org. Chem. 2006, 1535-1546. doi:10.1002/ejoc.200500887

41. Govender, T.; Hojabri, L.; Moghaddam, F. M.; Arvidsson, P. I. Tetrahedron: Asymmetry 2006, 17, 1763-1767. doi:10.1016/j.tetasy.2006.06.028

42. Sundén, H.; Ibrahem, I.; Zhao, G.-L.; Eriksson, L.; Córdova, A. Chem.-Eur. J. 2007, 13, 574-581. doi:10.1002/chem.200600572

43. Ibrahem, I.; Sundén, H.; Rios, R.; Zhao, G.-L.; Córdova, A. Chimia 2007, 61, 219-223. doi:10.2533/chimia.2007.219

44. Li, H.; Wang, J.; E-Nunu, T.; Zu, L.; Jiang, W.; Wei, S.; Wang, W. Chem. Commun. 2007, 507-509. doi:10.1039/B611502K

45. Luo, S.-P.; Li, Z.-B.; Wang, L.-P.; Guo, Y.; Xia, A.-B.; Xu, D.-Q. Org. Biomol. Chem. 2009, 7, 4539-4546. doi:10.1039/B910835A

46. Shen, H.; Yang, K.-F.; Shi, Z.-H.; Jiang, J.-X.; Lai, G.-Q.; Xu, L.-W. Eur. J. Org. Chem. 2011, 5031-5038. doi:10.1002/ejoc.201100613

47. Liu, C.; Zhang, X.; Wang, R.; Wang, W. Org. Lett. 2010, 12, 4948-4951. doi:10.1021/ol102096s

48. Alemán, J.; Núñez, A.; Marzo, L.; Marcos, V.; Alvarado, C.; Garcia Ruano, J. L. Chem.-Eur. J. 2010, 16, 9453-9456. doi:10.1002/chem.201001293

49. Alemán, J.; Alvarado, C.; Marcos, V.; Núñez, A.; Garcia Ruano, J. L. Synthesis 2011, 1840-1846. doi:10.1055/s-0030-1260020

50. Rios, R.; Sundén, H.; Ibrahem, I.; Córdova, A. Tetrahedron Lett. 2007, 48, 2181-2184. doi:10.1016/j.tetlet.2007.01.094

51. Xia, A.-B.; Xu, D.-Q.; Luo, S.-P.; Jiang, J.-R.; Tang, J.; Wang, Y.-F.; Xu, Z.-Y. Chem.-Eur. J. 2010, 16, 801-804. doi:10.1002/chem.200902540

52. Kotame, P.; Hong, B.-C.; Liao, J.-H. Tetrahedron Lett. 2009, 50, 704-707. doi:10.1016/j.tetlet.2008.11.106

53. Hong, B.-C.; Kotame, P.; Tsai, C.-W.; Liao, J.-H. Org. Lett. 2010, 12, 776-779. doi:10.1021/ol902840x

54. Sakakibara, T.; Koezuka, M.; Sudoh, R. Bull. Chem. Soc. Jpn. 1978, 51, 3095-3096.

55. Dauzonne, D.; Royer, R. Synthesis 1984, 348-349. doi:10.1055/s-1984-30841

56. Varma, R. S.; Kadkhodayan, M.; Kabalka, G. W. Synthesis 1986, 486-488. doi:10.1055/s-1986-31683

57. Yan, M.-C.; Jang, Y.-J.; Yao, C.-F. Tetrahedron Lett. 2001, 42, 2717-2721. doi:10.1016/S0040-4039(01)00284-2

58. Yao, C.-F.; Jang, Y.-J.; Yan, M.-C. Tetrahedron Lett. 2003, 44, 3813-3816. doi:10.1016/S0040-4039(03)00776-7

59. Korotaev, V. Y.; Sosnovskikh, V. Y.; Kutyashev, I. B.; Bakov, A. Yu.; Matochkina, E. G.; Kodess, M. I. Tetrahedron 2008, 64, 5055-5066. doi:10.1016/j.tet.2008.03.065
60. Xu, D.-Q.; Wang, Y.-F.; Luo, S.-P.; Zhang, S.; Zhong, A.-G.; Chen, H.; Xu, Z.-Y. Adv. Synth. Catal. 2008, 350, 2610-2616. doi:10.1002/adsc.200800535

61. Karthikeyan, T.; Sankararaman, S. Tetrahedron: Asymmetry 2008, 19 , 2741-2745. doi:10.1016/j.tetasy.2008.12.007

62. Das, B. C.; Mohapatra, S.; Cambell, P. D.; Nayak, S.; Mahaligam, S. M.; Evans, T. Tetrahedron Lett. 2010, 51, 2567-2570. doi:10.1016/j.tetlet.2010.02.143

63. Zhang, Z.; Jakab, G.; Schreiner, P. R. Synlett 2011, 1262-1264. doi:10.1055/s-0030-1259956

64. Wang, W.; Li, H.; Wang, J.; Zu, L. J. Am. Chem. Soc. 2006, 128, 10354-10355. doi:10.1021/ja063328m

65. Rios, R.; Sundén, H.; Ibrahem, I.; Zhao, G.-L.; Eriksson, L.; Córdova, A. Tetrahedron Lett. 2006, 47, 8547-8551. doi:10.1016/j.tetlet.2006.09.135

66. Rios, R.; Sundén, H.; Ibrahem, I.; Zhao, G.-L.; Eriksson, L.; Cordova, A. Tetrahedron Lett. 2006, 47, 8679-8682. doi:10.1016/j.tetlet.2006.10.028

67. Zu, L.; Wang, J.; Li, H.; Xie, H.; Jiang, W.; Wang, W. J. Am. Chem. Soc. 2007, 129, 1036-1037. doi:10.1021/ja067781+

68. Zu, L.; Xie, H.; Li, H.; Wang, J.; Jiang, W.; Wang, W. Adv. Synth. Catal. 2007, 349, 1882-1886. doi:10.1002/adsc.200700158

69. Zhao, G.-L.; Vesely, J.; Rios, R.; Ibrahem, I.; Sundén, H.; Córdova, A. Adv. Synth. Catal. 2008, 350, 237-242. doi:10.1002/adsc.200700407

70. Dodda, R.; Goldman, J. J.; Mandal, T.; Zhao, C.-G.; Broker, G. A.; Tiekink, E. R. T. Adv. Synth. Catal. 2008, 350, 537-541. doi:10.1002/adsc. 200700331

71. Dodda, R.; Mandal, T.; Zhao, C.-G. Tetrahedron Lett. 2008, 49, 1899-1902. doi:10.1016/j.tetlet.2008.01.113

72. Wang, J.; Xie, H.; Li, H.; Zu, L.; Wang, W. Angew. Chem., Int. Ed. 2008, 47, 4177-4179. doi:10.1002/anie.200800381

73. Sundén, H.; Rios, R.; Ibrahem, I.; Zhao, G. L.; Eriksson, L.; Córdova, A Adv. Synth. Catal. 2007, 349, 827-832. doi:10.1002/adsc.200600513

74. Li, H.; Wang, J.; Xie, H.; Zu, L.; Jiang, W.; Duesler, E. N.; Wang, W. Org. Lett. 2007, 9, 965-968. doi:10.1021/ol062877u

75. Yoshitomi, Y.; Arai, H.; Makino, K.; Hamada, Y. Tetrahedron 2008, 64, 11568-11579. doi:10.1016/j.tet.2008.10.032

76. Wang, Y.-F.; Zhang, W.; Luo, S.-P.; Li, B.-L.; Xia, A.-B.; Zhong, A.-G.; Xu, D.-Q. Chem.-Asian J. 2009, 4, 1834-1838. doi:10.1002/asia.200900298

77. Liu, X.; Lu, Y. Org. Biomol. Chem. 2010, 8, 4063-4065. doi:10.1039/C0OB00223B 


\section{License and Terms}

This is an Open Access article under the terms of the Creative Commons Attribution License

(http://creativecommons.org/licenses/by/2.0), which permits unrestricted use, distribution, and reproduction in any medium, provided the original work is properly cited.

The license is subject to the Beilstein Journal of Organic Chemistry terms and conditions:

(http://www.beilstein-journals.org/bjoc)

The definitive version of this article is the electronic one which can be found at:

doi:10.3762/bjoc.8.191 